\title{
CO-Pd-Ag И Th-REЕ МИНЕРАЛИЗАЦИЯ ВМЕЩАЮЩИХ ПОРОД ЭКЗОКОНТАКТОВОЙ ЗОНЫ МАССИВА ТАШЛЫ-ТАУ ХУДОЛАЗОВСКОГО КОМПЛЕКСА (ЮЖНЫЙ УРАЛ): УСЛОВИЯ ОБРАЗОВАНИЯ И ИСТОЧНИКИ ВЕЩЕСТВА
}

\author{
Рахимов Ильдар Рашитович1, \\ rigel92@mail.ru
}

\author{
Анкушева Наталья Николаевна², \\ ankusheva@mail.ru \\ Холоднов Владимир Васильевич 3 , \\ holodnov@igg.uran.ru \\ 1 Институт геологии УФИЦ РАН, \\ Россия, 450077, г. Уфа, ул. К. Маркса, 16/2. \\ 2 Институт минералогии ЮУ ФНЦ МиГ УрО РАН, \\ Россия, 456317, г. Миасс, Ильменский заповедник, 1. \\ 3 Институт геологии и геохимии им. А.Н. Заварицкого УрО РАН, \\ Россия, 620016, г. Екатеринбург, ул. Ак. Вонсовского, 15.
}

\begin{abstract}
Актуальность. Экзоконтактовые породы рудоносных массивов худолазовского дифрференцированного комплекса практически не изучены на предмет геохимических характеристик и рудной минерализации.

Цель: минералого-геохимическая характеристика пород экзоконтактовой зоны массива Ташлы-Тау и оценка состава и РTпараметров минералообразующего фрлюида.

Методы: полевые геологические работы, оптическая и электронная микроскопия, рентгеноспектральный (EDS u WDS) анализ состава минералов, XRF и ICP MS анализ химического состава пород.

Результаты. Впервые в экзоконтактовых породах массивов худолазовского комплекса обнаружена Co-Pd-Ag u Th-REE мuнерализация, представленная самостоятельными минеральными фразами Fe-Ni-кобальтина, Fe-Co-герсдорфита, майчнерита, гессита, монацита. Выделены зоны дальнего и ближнего экзоконтакта рудоносного массива Ташль-Тау, различающиеся по степени метаморфизма и метасоматоза вмещающих его песчаников. В зоне ближнего экзоконтакта развиты кварикальцитовые жилы, несущие Co-Pd-Ag минерализацию. В сульфоорсенидах обнаружена примесь $P d(\partial о$ 0,44 \%), прямо коррелирующая с содержанием Ni. Кварцевые и квари-хлорит-полевошпатовые жилы зон ближнего и дальнего экзоконтакта несут рассеянную Th-REE минерализацию. Кроме того, в кварцевых жилах поздней генерации были обнаружены зёрна гётитгематитового состава, содержащие примеси $P d$ (до 0,17-0,32 \%) и $R$ h (до 0,03 \%). Установлено, что источником Cо-Pd-Ag минерализации вмещающих пород является сам массив Ташлы-Тау, породы и руды которого на постмагматическом этапе были переработаны гидротермальным фрлюидом. В качестве источника Th-REE минерализации экзоконтактовой зоны предполагаются породы биягодинской свиты (песчаники с глинистым цементом). По данным термобарогеохимии ранние сульфидно-кварцевые и поздние сульфидно-квари-карбонатные жилы отлагались при остывании единого гидротермального Na-KМg-хлоридного фрлюида при температуре от 370-320 до 280-250 C и его разбавлении от 10,6 до 6 мас. \%, соответственно.
\end{abstract}

\section{Ключевые слова:}

Экзоконтактовая зона, минералогия, литология, литохимия, кобальтин-герсдорфитовый твёрдый раствор, монацит, квари, кальцит, фрлюидные включения.

\section{Введение}

Худолазовский дифференцированный комплекс стал широко известен в геологической литературе с 60-70-х гг. XX в. после проведения поисковоразведочных работ на медно-никелевые руды [Бучковский и др., 1974ф]. В результате был выявлен ряд рудопроявлений с общими запасами $\mathrm{Cu}+\mathrm{Ni}+\mathrm{Co}$ 570-590 тыс. т.

В начале 1980-х гг. при детальном петрографическом изучении было выявлено значительное влияние постмагматических процессов на формирование сульфидной минерализации [1], однако не были установлены минеральные парагенезисы, РТ-условия предполагаемого метаморфизма, свойства гидротермального флюида и другие особенности. К тому же, на тот момент не было известно о наличии благороднометалль- ной минерализации, связанной с сульфидными рудами. Постепенно, в том числе в связи с заключением о слабом промышленном потенциале руд худолазовского комплекса, интерес к его изучению угас.

Научный интерес в отношении комплекса возродился в последние три года благодаря открытию Pt-Pd минерализации (сперрилит, мончеит, майчнерит, фрудит, садбериит, боровскит), локализованной внутри сульфидных фаз (халькопирита, пирротина и реже пентландита) [2, 3]. Детальные минералогогеохимические исследования показали, что платинометалльная минерализация, как и сульфидная, имеет полигенный характер, что связано с гидротермальнометасоматической переработкой рудоносных пород. Это способствовало растворению рудных минералов в нижних рудных зонах массивов, а слагающие их 
компоненты выносились и переотлагались как в их верхних частях, так и во вмещающих породах [4]. В результате были сформированы не только новые морфологические типы минералов (амёбовидные, тонкодисперсные, пластинчатые и др.), ассоциирующие с низкотемпературными карбонатами и силикатами, но и новые минеральные фазы (пирит, виоларит, золото, $\mathrm{Sb}$-майчнерит и другие Ві-теллуриды).

Таким образом, проведённые минералогогеохимические исследования показали, что экзоконтактовые зоны массивов худолазовского комплекса также являются перспективными на выявление благороднометалльной минерализации. На данном этапе исследований контактово-метасоматическая минерализация наиболее изучена для экзоконтактовой зоны массива Tашль-Tay.

Целью данной работы является детальная минералого-геохимическая характеристика пород и руд экзоконтактовой зоны массива Ташлы-Тау с оценкой состава и РТ-параметров минералообразующего флюида.

\section{Методы исследования}

Лабораторная коллекция образцов из массива Ташлы-Тау и вмещающих пород (21 шт.) включала штуфные пробы из обнажённых участков массивов и керна скважин 1969-1971 гг. Изучено около 30 шлифов и аншлифов пород и руд на оптическом микроскопе Carl Zeiss Axioskop 40.

Определение состава силикатных и сульфидных минералов выполнено при помощи электронно-зондового микроанализатора JEOL JXA-8230 в Центре коллективного пользования много-элементных и изотопных исследований Института геологии и минералогии СО РАН (ЦКП МИИ СО РАН, аналитик Е.Н. Нигматулина) в г. Новосибирск. Градуирование осуществлялось по внутренним стандартам, ускоряющее напряжение 20 кВ, ток 30 нА, диаметр пучка 2 мкм.

Электронно-микроскопические исследования рудной минерализации проведены на сканирующем электронном микроскопе Tescan Vega3 LMH также в ЦКП МИИ СО РАН (аналитик М.В. Хлестов). Химический состав минералов определён в режиме EDS c использованием приставки INCA X-MAX $50 \mathrm{~mm}$ фирмы Oxford Instruments: напряжение 20 кВ, сила тока 15 нА, вакуум 0,05 Па, диаметр пучка 2 мкм, пределы допускаемой относительной погрешности измерений $\pm 3 \%$. В качестве внутреннего стандарта использовался чистый кобальт.

Микроэлементный состав пород определён методом ICP MS на квадрупольном масс-спектрометре ELAN 9000 Perkin Elmer в ЦКП «Геоаналитик» Института геологии и геохимии УрО РАН (ИГГ УрО РАН, г. Екатеринбург, аналитики Д.В.Киселева и Н.В.Чередниченко). Разложение образцов пород, в зависимости от их состава, проводилось путём кислотного вскрытия как в открытой, так и в закрытой системах. Для работы использовался аргон чистоты 99,998 \%. Перед началом измерений осуществлялась оптимизация операционных параметров оборудования для достижения максимальной чувствительности ионов $\mathrm{M}^{+}$и минимизации сигналов от $\mathrm{M}^{2+}, \mathrm{MO}^{+}$и фона в области $\mathrm{m} / \mathrm{z}=220$. Типичные операционные условия масс-спектрометра ELAN 9000 при мультиэлементном анализе проб следующие: мощность радиочастотного генератора - 1300 Вт, материал конусов интерфейса - платина или никель. Для построения градуировочных зависимостей применялись мультиэлементные стандартные растворы

Для оценки температур минералообразования, солевого состава рудообразующих растворов флюидные включения в кварце и кальците были проанализированы в микротермокамере TMS-600 (Linkam), позволяющей производить измерения температур фазовых переходов в интервале от -196 до $+600^{\circ} \mathrm{C}$, с оптическим микроскопом Olympus BX 51 (лаборатория термобарогеохимии Южно-Уральского государственного университета, г. Миасс). Погрешность измерительной аппаратуры составляет $\pm 0,1^{\circ} \mathrm{C}$ в интервале $-20 \ldots+80{ }^{\circ} \mathrm{C}$ и $\pm 1{ }^{\circ} \mathrm{C}-$ за пределами этого интервала. Использовалось программное обеспечение LinkSys 32 DV-NC. Солевой состав растворов во включениях оценивался по температурам эвтектик [5]. Концентрации солей в растворах рассчитывались по температурам плавления последних кристаллических фаз по данным [6]. Результаты приведены по 70 измерениям, статистическая обработка выполнена в программе Statistica 12.

\section{Результаты исследований}

Краткая геологическая и литологическая характеристика экзоконтактовой зоны массива Ташлы-Тау

Массив Ташлы-Тау худолазовского дифференцированного комплекса представляет собой шток, сложенный метасоматизированными роговообманковыми плагиоперидотитами и габбро с пойкилоофитовой структурой [3]. В плане интрузия имеет слегка вытянутую форму (длиной до 150 м и шириной до 120 м), мощность по единственной скважине принята за 112 м (рис. 1). Шток локализован на западном крыле Худолазовской мульды среди песчаников нижней подсвиты биягодинской свиты верхнего девона $\left(\mathrm{D}_{3} \mathrm{f}-\mathrm{fm}\right)$. Мощность песчано-кремнистой подсвиты достигает 550-650 м [7]. Падение толщи песчаников в зоне массива Ташлы-Тау восточное, угол падения $22^{\circ}$. Породы биягодинской свиты залегают на кремнистых сланцах мукасовской свиты и перекрываются глинисто-терригенными образованиями зилаирской свиты, выполняющими ядро Худолазовской мульды. Породы западного крыла мульды, в том числе и биягодинской свиты, кливажированы, что связано с тектоническими процессами, проявившимися после формирования Худолазовской структуры.

В зоне внедрения интрузии вмещающие породы метаморфизованы (ороговикованы) и прорваны многочисленными жилами кварц-хлорит-полевошпатового и кварцевого (реже кальцит-кварцевого) состава. Характер взаимных пересечений этих жил позволяет выделять ранние и поздние по времени формирования жилы (рис. 2). Мощность экзоконтаковой зоны неравномерная - от 1-3 до 15-20 м, и предварительно установлено, что она увеличивается к западу от интрузии (рис. $1, \sigma, \varepsilon)$. 

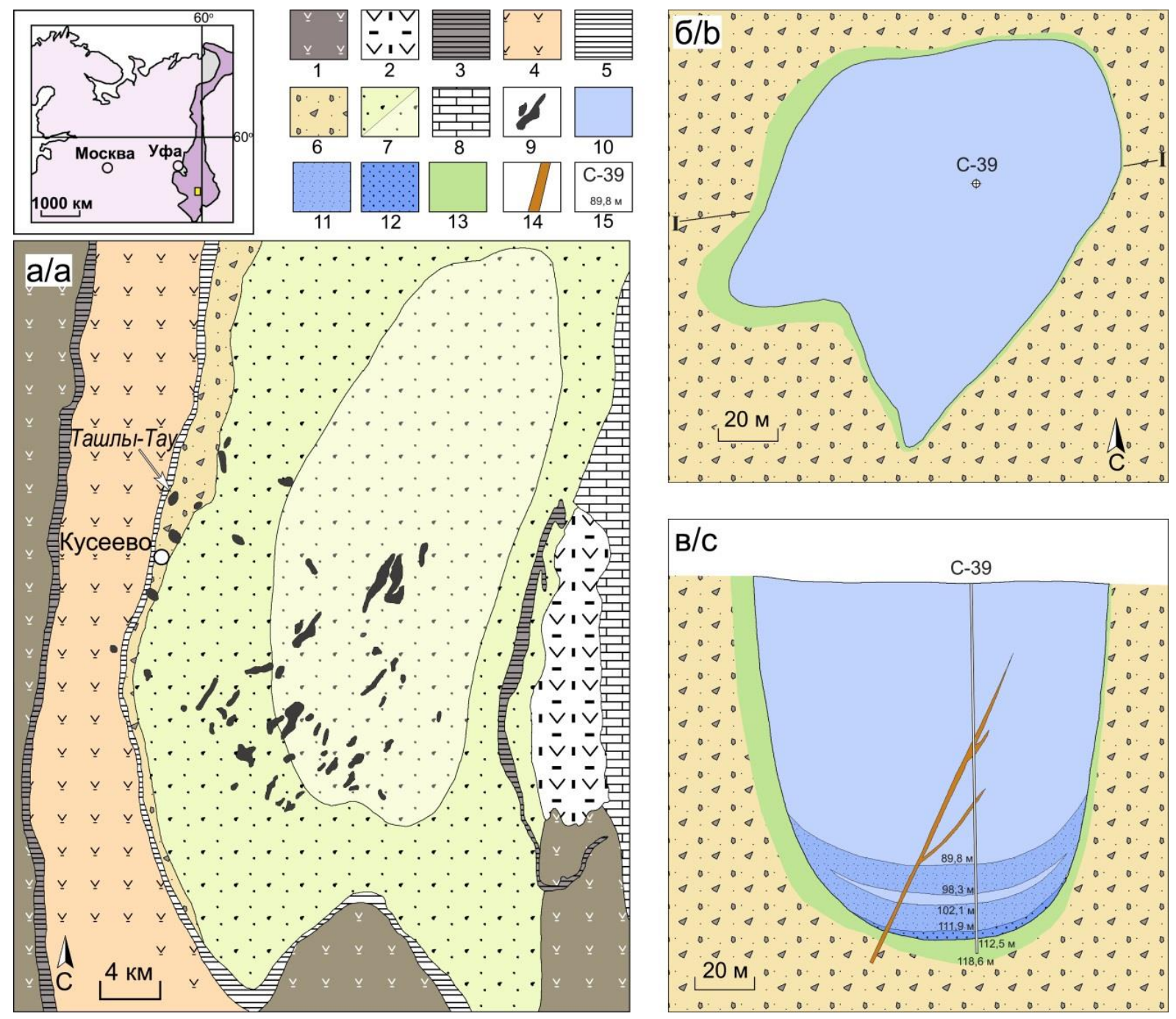

Рис. 1. Схема геологического строения Худолазовской мульды (а) и форма (в плане) массива Ташль-Тау (б) с геологическим разрезом по линии I-I (в) по [Бучковский и др., 1974ф]. Условные обозначения: 1 - вулканогенные толщии ирендыкской свиты $\left(D_{2} e f_{1}\right) ; 2$ - вулканогенные толщи карамалыташской свиты $\left(D_{2} e f_{2}\right) ; 3$ - кремнистые отложения ярльккаповской свиты $\left(D_{2} e f_{2}\right) ; 4$ - вулканогенно-осадочные толщи улутауской свиты $\left(D_{2-}\right.$ зzv-f); 5 - кремнистые отложения мукасовской свиты $\left(D_{3} f\right) ; 6$ - вулканогенно-осадочные образования бияго-

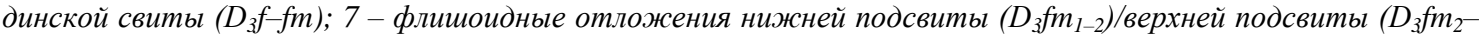
$\left.C_{l} t_{l}\right)$ зилаирской свиты; 8 - вулкано-терригенно-карбонатные отложения берёзовской свиты $\left(C_{l} t-v\right) ; 9-$ интрузии худолазовского комплекса $\left(C_{l} v-s\right) ; 10$ - роговообманковые плагиоперидотиты и габбро с редкой сульфидной вкрапленностью; 11 - убогие руды (Ni<0,3\%); 12 - рядовые руды (Ni 0,3-1\%); 13 - зона экзоконтакта; 14 - дайки роговообманковых долеритов; 15 - номер скважины и интервалы рудных тел

Fig. 1. Geological scheme of Khudolaz. Trough (a) and shape (in the plane view) of Tashly-Tau massif (b) with I-I geological section (c), after [Buchkovskiy et al., 1974f]: 1 - volcanogenic rocks of Irendyk Suite $\left(D_{2} e f_{1}\right) ; 2$ volcanogenic rocks of Karamalytash Suite $\left(D_{2} e f_{2}\right) ; 3$ - siliceous sediments of Yarlykapovo Suite $\left(D_{2} e f_{2}\right) ; 4$ volcanogenic-sedimentary rocks of Ulutau Suite $\left(D_{2-3} z v-f\right) ; 5$ - siliceous sediments of Mukas Suite $\left(D_{3} f\right) ; 6$ volcanogenic-sedimentary rocks of Biyagoda Suite $\left(D_{3} f-f m\right) ; 7$ - flyschoid sediments of Early $\left(D_{3} f m_{1-2}\right) / L a t e\left(D_{3} f m_{2-}\right.$ $\left.C_{l} t_{l}\right)$ Subsuites of Zilair Suite; 8 - volcanic-terrigenic-carbonate sediments of Beryzovskiy Suite $\left(C_{l} t-v\right) ; 9-$ Khudolaz complex intrusions $\left(C_{1} v-s\right) ; 10$ - hornblende plagioperidotites and gabbroes with disseminated sulfides; 11 - poor ores $(\mathrm{Ni}<0,3 \%) ; 12$ - ordinary ores (Ni 0,3-1\%); 13 - exocontact zone; 14 - hornblende dolerite dykes; 15 - borehole numbers and ore body intervals

Песчаники, вмещающие массив Ташлы-Тау в целом являются довольно типичными для биягодинской свиты [8]. Это кварцевые граувакки (рис. 3, a) с содержанием обломков кварца $45 \%$, кварцитов - $35 \%$, метавулканитов - $15 \%$, рудных минералов (изменённые титаномаг- нетит, ильменит, рутил, хромит) - 5 \%. Цемент песчаников кремнисто-хлорит-гётит-глинистый поровоплёночного типа, образовавшийся за счёт разложения тефрогенного материала. Редко встречаются обломки кислого плагиоклаза и амфибола (часто хлоритизиро- 
ванного). Хлорит иногда образует мелкие жеодовидные выделения. Материал кластов был достаточно хорошо отсортирован, по крупности породы соответствуют мелко- и среднезернистым песчаникам $(0,1-0,4$ мм, в среднем 0,2 мм). Однако обломки имеют разную степень окатанности: к примеру, кварцевые зёрна имеют степень окатанности от 0 до 4 (по шкале Л.Б. Рухина).

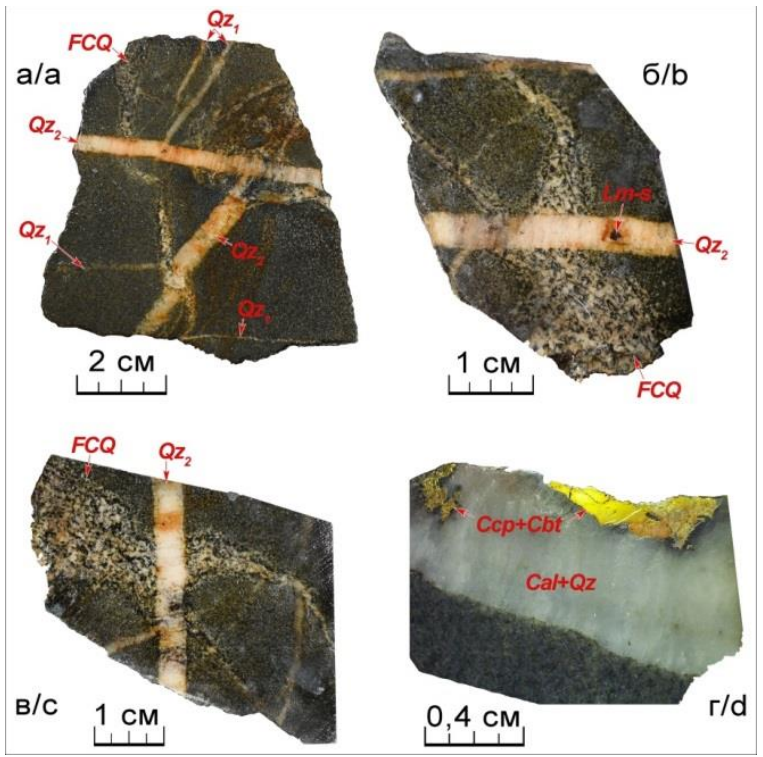

Рис. 2. Примеры соотнотений жил квариевого $\left(Q z_{1}\right.$ и $Q z_{2}, \quad \mathrm{Lm}-\mathrm{s}$ - лимонитизированное $\mathrm{Ni}-\mathrm{Cu}$ содержащее сульфидное зерно), квари-хлоритполевошпатового (FCQ) и квари-карбонатного $(\mathrm{Cal}+Q z \quad c \quad$ халькопиритом $и$ кобальтином $(C c p+C b t))$ состава в метапесчаниках экзоконтактовой зоны массива Ташль-Тау: а-в) обр.

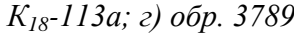

Fig. 2. Examples of interaction between quartz $\left(Q z_{1} u Q z_{2}\right.$, $\mathrm{Lm}$-s - limonitized $\mathrm{Ni}$-Cu-containing sulfide grain), quartz-chlorite-feldspar (FCQ) and quartzcarbonate $(\mathrm{Cal}+Q z$ with chalcopyrite and cobaltite $(C c p+C b t))$ veins in metamorphosed sandstones from exocontact zone of Tashly-Tau massif. Samples. a-c) $K_{18^{-}} 113 a$; d) 3789

В зоне дальнего эндоконтакта происходит изменение количественных соотношений минералов и структуры песчаников. За счёт кварцитовых и кварцевых обломочных зёрен возникает новообразованный кварц, имеющий сложную морфологию и находящийся в срастании с новообразованным чешуйчатым хлоритом (рис. 3, б). Цемент песчаников, представленный глинистым материалом, а также обломочные зёрна полевых шпатов и магнетита (частично) переходят в новообразованные глинистые фазы, предположительно отвечающие ожелезнённым смешаннослойным силикатам. Структура таких пород приобретает черты нематобластовой (как в сланцах) и неравномернозернистой (как в интрузивных породах). Практически весь ильменит превращён в лейкоксен, а по магнетиту образованы гематит и гётит.

В зоне ближнего экзоконтакта развиты роговики, сочетающие неравномернозернистую и лепидобластовую, пойкилобластовую структуры (рис. 3, в, г).
За счёт глинистого матрикса формируются сплошные агрегаты тонкочешуйчатого серицита, а также полевые шпаты - альбит, калиевый полевой шпат. Более того, в этих породах встречаются жиловидные внедрения кварц-хлорит-полевошпатового (FCQ) состава (рис. 3, d), напоминающие мелкие апофизы. Их наличие связывается с образованием внутри метаморфизующихся толщ песчаников небольших объёмов жидкого флюида (или расплава?), мигрирующего в стороны от габброидного массива. В новообразованных породах сильно сокращается количество кварца, поскольку он переходит в раствор/расплав, из которого образуются маломощные жилы (от 0,5-1 мм до 1-2 см), которыми пронизаны породы всей зоны экзоконтакта. Ближе к интрузивному телу количество жил существенно возрастает. Выявлены две генерации кварцевых жил - ранняя $\left(\mathrm{Qz}_{1}\right)$ и поздняя $\left(\mathrm{Qz}_{2}\right)$. Ранняя генерация представлена тонкими извилистыми жилами, прорванными жилами FCQ-состава. В свою очередь, более мощные и прямолинейные кварцевые жилы поздней генерации повсеместно секут FCQ жилы (рис. 2, $a-8$ ). Морфология жил $\mathrm{Qz}_{2}$ обусловлена «залечиванием» ими трещин. По всей видимости, этап трещинообразования во вмещающем комплексе был связан с остыванием интрузивного тела. В непосредственной близости от интрузии появляются также смешанные карбонатно-кварцевые и кварц-карбонатные, а также самостоятельные карбонатные жилы (рис. 3, ж), несущие рудную минерализацию (рис. 2, г).

Геохимическая характеристика пород массива Ташлы-Тау и его экзоконтактовой зоны

Породы массива Ташлы-Тау представляют собой магматиты, переходные от ультраосновных к основным, имеющие следующие петрохимические индексы: $\mathrm{Mg \#} \quad\left(100 \times \mathrm{MgO} /\left(\mathrm{FeO}_{\mathrm{t}}+\mathrm{MnO}+\mathrm{MgO}\right)\right)=42-57, \quad \mathrm{Al \#}$ $\left(100 \times \mathrm{Al}_{2} \mathrm{O}_{3} /\left(\mathrm{FeO}_{\mathrm{t}}+\mathrm{MgO}\right)\right)=32-61, \quad \mathrm{Na}_{2} \mathrm{O} / \mathrm{K}_{2} \mathrm{O}=1-12$. Содержания $\mathrm{Ni}$ и $\mathrm{Cu}$ в породах варьируют в пределах $0,02-0,05$ и $0,01-0,1 \%$ соответственно, а в рудах достигают значений $0,5 \% \mathrm{Ni}$ и $2 \% \mathrm{Cu}$.

Неизменённые песчаники характеризуются следующими значениями петрохимических модулей по [9]: гидролизатный модуль $\Gamma \mathrm{M}=0,30$, алюмокремниевый модуль АМ=0,17, железистый модуль ЖМ=0,69, титановый модуль ТМ=0,06, модуль нормированной щёлочности НКМ=0,32. В зоне экзоконтакта по мере увеличения степени метаморфизма песчаников значения этих модулей возрастают (кроме НКМ): ГМ=0,46-0,65, $\mathrm{AM}=0,24-0,33$, ЖМ=0,80-0,93, ТM=0,06-0,09. Величина НКМ снижается до 0,25-0,29. Таким образом, контактово-метасоматические процессы вмещающих песчаников привели к выносу $\mathrm{SiO}_{2}$, и Са и к привносу $\mathrm{Al}, \mathrm{Ti}, \mathrm{Fe}, \mathrm{K}$ и $\mathrm{S}$ (табл. 1). Из примесных элементов наиболее существенны различия в концентрациях As, $\mathrm{Co}, \mathrm{Cu}$, количества которых во вмещающих породах возрастают по мере приближения к интрузии (табл. 1). Приконтактовые роговики обогащены $\mathrm{Cu}$ (до 0,4-0,6 \%), Ni (до 300 г/т), Cо (до 110-125 г/т), As (до 205-699 г/т), $\mathrm{Pb}$ (до 30-48 г/т) в сравнении с более удалёнными от интрузии вмещающими породами. 


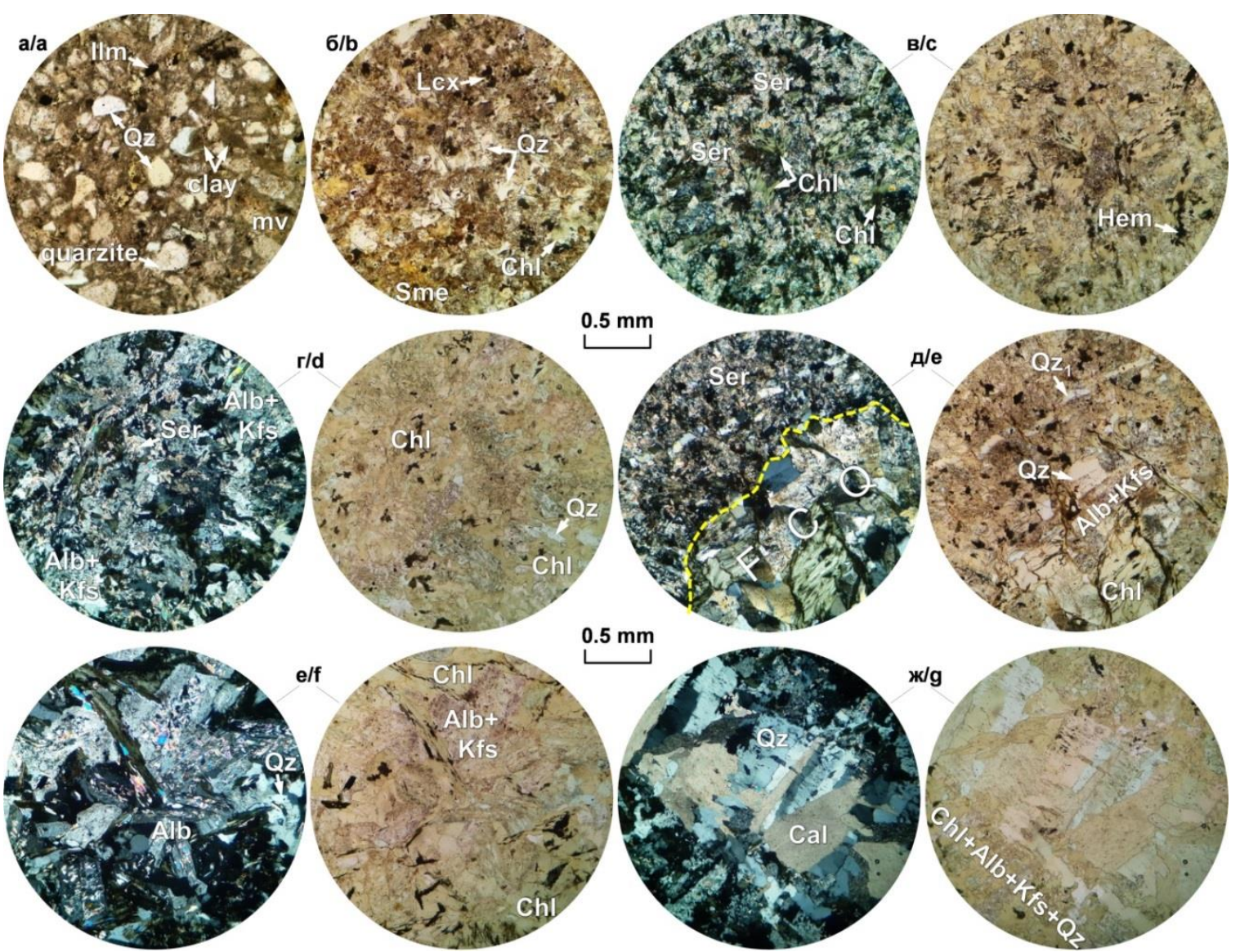

Рис. 3. Вмещающие породы массива Ташль-Тау (проходящий свет): а) песчаник за пределами зоны экзоконтакта; б) метапесчаник из зоны дальнего экзоконтакта; в) серицит-квари-хлоритовый роговик (с анализатором/без анализатора); г) серицит-квари-хлорит-полевошпатовый роговик (с анализатором/без анализатора); д) квариевая $\left(Q z_{l}\right)$ и квари-хлорит-полевошпатовая (FCQ) жиль в серицит-квари-хлоритовом роговике (c анализатором/без анализатора); е) детализаиия структуры пород квари-хлорит-полевошпатовой (FCQ) жиль (с анализатором/без анализатора); ж) квари-карбонатная жила в роговике зоны ближнего экзоконтакта (с анализатором/без анализатора). Примечание: Alb - альбит, Cal - кальцит, Chl - хлорит, clay глинистый материал, Нет - гематит, Ilm - ильменит, Kfs - калиевый полевой шпат, Lcx - лейкоксен, mv метавулканит (обломки), Ser - серицит, Sте - смектит, $Q z$ - квари, quartzite - кварцит (обломки)

Fig. 3. Host rocks of Tashly-Tau massif (transmitted light): a) sandstone out of the exocontact zone; b) metamorphosed sandstone from far exocontact zone; c) sericite-quartz-chlorite horn (XPL/PPL); d) sericite-quartz-chlorite-feldspar horn (XPL/PPL); e) quartz $\left(Q z_{1}\right)$ and quartz-chlorite-feldspar (FCQ) vein in sericite-quartz-chlorite horn (XPL/PPL), f) detail photo of quartz-chlorite-feldspar (FCQ) vein structure (XPL/PPL) (with/without an analyzer); g) quartzcarbonate vein in horn from the near exocontact zone (XPL/PPL). Note: Alb - albite, Cal - calcite, Chl - chlorite, clay - clayey material, Hem - hematite, Ilm - ilmenite, Kfs - K-feldspar, Lcx - leucoxene, mv - metamorphosed vщoulcanite (clasts), Ser-sericite, Sme - smectite, Qz-quartz, quartzite - quartzite (clasts)

\section{Минералогия пород экзоконтактовой зоны}

Главными минералами метапесчаников-роговиков являются: кварц, хлорит, глинистые минералы (смектиты), серицит, полевые шпаты (альбит, калиевый полевой шпат). В небольшом количестве, но повсеместно, распространены гидроксиды железа (гётит и др.). В зоне ближнего экзоконтакта широко развит кальцит. В силикатной матрице обнаружены многочисленные новообразованные кристаллы лейкоксенизированного ильменита, титанита, апатита, клиноцоизита.

Квари представлен обычно изометричными зёрнами размером 0,1-0,3 мм, характеризующимися блоковым и волнистым погасанием в шлифах. Часто они образуют сростки, окружённые кристаллами хлорита и полевых шпатов (рис. 3, б, г, д). Количество кварца в породах ближнего экзоконтакта не превышает 10-15 об. \%, тогда как в метапесчаниках зоны дальнего экзоконтакта оно составляет 25-30 \% (до 70 \%). По данным микрозондового анализа кварц является «химически чистым», среди выявленных примесей значимы только $\mathrm{Fe}(0,01-0,05 \%)$ и $\mathrm{F}(0,05-0,08 \%)$.

Альбит распространён в роговиках зоны ближнего экзоконтакта в виде ксеноморфных или субидиоморфных кристаллов таблитчатого облика в количестве до 12 об. \%. В зоне дальнего экзоконтакта альбит развит в основном в составе FCQ жил, где он представлен субидиоморфными призматическими зёрнами (рис. $3, e$ ). Количество анортитового минала в альбите варьирует - $\mathrm{An}_{1,6-6,5} \mathrm{Ab}_{92,9-97,9} \mathrm{Or}_{0,4-0,6}$. 
Таблица 1. Химический состав типовых габброидов массива Ташль-Тау (№ 6, 7) и вмещающих его пород биягодинской свиты (№ 1-5)

Table 1. Chemical composition of typical gabbroids from Tashly-Tau massif (№ 6, 7) and Byagoda Suite host rocks (№ 1-5)

\begin{tabular}{|c|c|c|c|c|c|c|c|}
\hline № пробы/Samp. No. & $K_{18}-96$ & $K_{18}-97$ & $K_{18}-113 a$ & $K_{18}-113 b$ & 3789 & 3775 & 3780 \\
\hline Элемент/Element & 1 & 2 & 3 & 4 & 5 & 6 & 7 \\
\hline $\mathrm{SiO}_{2}$ & 57,34 & 64,84 & 49,09 & 51,24 & 51,32 & 42,12 & 45,47 \\
\hline $\mathrm{TiO}_{2}$ & 0,79 & 0,7 & 1,51 & 1,34 & 0,95 & 0,59 & 0,72 \\
\hline $\mathrm{Al}_{2} \mathrm{O}_{3}$ & 13,94 & 11,24 & 15,99 & 15,12 & 14,06 & 10,51 & 13,91 \\
\hline $\mathrm{FeO}_{\mathrm{t}}$ & 11,54 & 8,09 & 14,05 & 13,65 & 13,64 & 17,39 & 13,02 \\
\hline $\mathrm{MnO}$ & 0,19 & 0,13 & 0,26 & 0,25 & 0,24 & 0,29 & 0,2 \\
\hline $\mathrm{MgO}$ & 7 & 5 & 7,14 & 7,43 & 3,22 & 15,3 & 9,92 \\
\hline $\mathrm{CaO}$ & 0,98 & 3,43 & 1,43 & 1,43 & 3,84 & 6,76 & 8,4 \\
\hline $\mathrm{Na}_{2} \mathrm{O}$ & 3,2 & 3,2 & 3,26 & 3,04 & 2,8 & 1,02 & 2,79 \\
\hline $\mathrm{K}_{2} \mathrm{O}$ & 0,27 & 0,37 & 1,22 & 1 & 1,24 & 0,09 & 0,37 \\
\hline $\mathrm{P}_{2} \mathrm{O}_{5}$ & 0,19 & 0,21 & 0,24 & 0,21 & 0,29 & 0,25 & 0,23 \\
\hline $\mathrm{SO}_{3}$ & 0,01 & 0,01 & 0,03 & 0,03 & 0,95 & 0,47 & 0,27 \\
\hline LOI & 4,38 & 1,78 & 4,90 & 4,54 & 6,48 & 4,6 & 3,69 \\
\hline Sum & 99,84 & 99 & 99,11 & 99,27 & 99,02 & 99,37 & 99 \\
\hline $\mathrm{Sc}$ & 13 & 12 & 18 & 23 & 15 & 15 & 16 \\
\hline $\mathrm{V}$ & 90 & 80 & 140 & 140 & 120 & 90 & 90 \\
\hline $\mathrm{Cr}$ & 180 & 260 & 130 & 150 & 200 & 490 & 250 \\
\hline Co & 17 & 16 & 20 & 17 & 110 & 80 & 42 \\
\hline $\mathrm{Ni}$ & 140 & 150 & 220 & 240 & 300 & 600 & 250 \\
\hline $\mathrm{Cu}$ & 28 & 26 & 90 & 110 & 4000 & 460 & 210 \\
\hline $\mathrm{Zn}$ & 50 & 40 & 70 & 70 & 70 & 60 & 50 \\
\hline As & 20 & 4 & 22 & 23 & 205 & 3 & 7 \\
\hline $\mathrm{Se}$ & 0,33 & 0,43 & 0,37 & 0,43 & 1,9 & 1,08 & 0,61 \\
\hline $\mathrm{Rb}$ & 7 & 14 & 21 & 25 & 25 & 3 & 8 \\
\hline $\mathrm{Sr}$ & 270 & 300 & 260 & 250 & 220 & 130 & 300 \\
\hline $\mathrm{Y}$ & 17 & 17 & 17 & 20 & 19 & 13 & 12 \\
\hline $\mathrm{Zr}$ & 68 & 82 & 150 & 110 & 130 & 73 & 59 \\
\hline $\mathrm{Nb}$ & 5,5 & 5,8 & 10 & 9 & 8 & 2,4 & 2 \\
\hline Mo & 0,22 & 0,5 & 0,5 & 0,4 & 0,5 & 0,6 & 0,4 \\
\hline $\mathrm{Ag}$ & 0,08 & 7,7 & 4,1 & 2,7 & 4,2 & 5,2 & 0,13 \\
\hline $\mathrm{Sb}$ & 0,07 & 0,13 & 0,13 & 0,12 & 0,4 & 0,1 & 0,08 \\
\hline $\mathrm{Te}$ & 0,02 & 0,02 & 0,02 & 0,02 & 0,7 & 0,06 & 0,06 \\
\hline Cs & 0,2 & 0,41 & 0,7 & 0,6 & 1,7 & 0,5 & 0,6 \\
\hline $\mathrm{Ba}$ & 60 & 100 & 160 & 110 & 150 & 23 & 60 \\
\hline $\mathrm{La}$ & 14 & 13 & 12 & 13 & 14 & 6 & 5 \\
\hline $\mathrm{Ce}$ & 28 & 25 & 25 & 28 & 29 & 13 & 12 \\
\hline $\operatorname{Pr}$ & 3,6 & 3,2 & 3,1 & 3,5 & 3,4 & 1,8 & 1,7 \\
\hline $\mathrm{Nd}$ & 14 & 13 & 13 & 14 & 14 & 8 & 7 \\
\hline $\mathrm{Sm}$ & 3 & 2,8 & 2,7 & 3 & 3 & 1,9 & 1,8 \\
\hline $\mathrm{Eu}$ & 0,6 & 0,8 & 0,7 & 0,9 & 0,9 & 0,6 & 0,6 \\
\hline $\mathrm{Gd}$ & 3 & 2,9 & 2,9 & 3,1 & 3,2 & 2,1 & 2,1 \\
\hline $\mathrm{Tb}$ & 0,4 & 0,4 & 0,4 & 0,4 & 0,4 & 0,3 & 0,3 \\
\hline Dy & 2,6 & 2,4 & 2,6 & 2,7 & 2,8 & 2 & 2 \\
\hline Ho & 0,5 & 0,5 & 0,5 & 0,6 & 0,6 & 0,4 & 0,4 \\
\hline $\mathrm{Er}$ & 1,5 & 1,4 & 1,6 & 1,6 & 1,7 & 1,2 & 1,2 \\
\hline $\mathrm{Tm}$ & 0,2 & 0,2 & 0,23 & 0,24 & 0,25 & 0,16 & 0,16 \\
\hline $\mathrm{Yb}$ & 1,3 & 1,3 & 1,5 & 1,5 & 1,6 & 1,1 & 1 \\
\hline $\mathrm{Lu}$ & 0,19 & 0,19 & 0,22 & 0,23 & 0,24 & 0,16 & 0,16 \\
\hline $\mathrm{Hf}$ & 1,4 & 1,5 & 2,5 & 1,9 & 2,3 & 1,2 & 1,1 \\
\hline $\mathrm{Ta}$ & 0,29 & 0,25 & 0,43 & 0,43 & 0,4 & 0,12 & 0,12 \\
\hline $\mathrm{Pb}$ & 3,2 & 6 & 10 & 3 & 30 & 1,4 & 4 \\
\hline $\mathrm{Bi}$ & 0,03 & 0,04 & 0,03 & 0,02 & 0,9 & 0,09 & 0,07 \\
\hline $\mathrm{Th}$ & 3,1 & 2,6 & 2,3 & 2,7 & 3,4 & 0,7 & 0,8 \\
\hline $\mathrm{U}$ & 1 & 0,8 & 1,1 & 1 & 1,3 & 0,21 & 0,24 \\
\hline
\end{tabular}

Примечание: петрогенные в мас. \%, микроэлементы в г/m; 1 - породы дальнего экзоконтакта, 2 - неметаморфизованный песчаник, 3-5 - породы ближнего экзоконтакта 6, 7- габброиды.

Note: the oxides are in $w t . \%$, trace elements are in ppm; 1 - far exocontact rocks, 2 - non-metamorphosed sandstone, 3-5near exocontact rocks; 6, 7 -gabbroids. 
Калиево-натриевые и калиевые полевые ипаты (КПШ) развиты совместно с альбитом в роговиках зоны ближнего экзоконтакта (до 15 об. \%) и в FCQ жилах, образуя призматические кристаллы с сильно корродированными краями (рис. $3,2, e)$. Их состав значительно варьирует (от анортоклаза до чистого ортоклаза) - $\mathrm{An}_{0,7-19,8} \mathrm{Ab}_{3,5-68,5} \mathrm{Or}_{11,6-94,5}$.

Хлорит является основным и часто единственным магнезиально-железистым силикатом изучаемых пород. Морфология его выделений в породах сильно различается. В метапесчаниках зоны дальнего экзоконтакта хлорит представлен в виде жеодовидных стяжений в смеси с гётитом, ассоциирующих с глинистыми минералами (рис. 3, б, в). В породах зоны ближнего экзоконтакта он образует чешуйчатые кристаллы удлинённой формы (рис. 3, e), а в жилах FCQсостава встречаются радиально-лучистые агрегаты хлорита. По химическому составу хлорит из близконтактовой зоны, ассоциирующий с полевыми шпатами и сульфидовмещающим кальцитом, отвечает рипидолиту $(\mathrm{Fe} /(\mathrm{Fe}+\mathrm{Mg})>0,4)$ и пикнохлору $(\mathrm{Fe} /(\mathrm{Fe}+\mathrm{Mg})<0,4)$. В хлорите были выявлены примеси $(\%)$ : F $(0,08-0,19)$ $\mathrm{Cl}(0,001-0,01), \mathrm{S}(0,002-0,01)$.

Кальц̧ит широко развит в близконтактовых породах, где он образует либо самостоятельные, либо совместные с кварцем жилы (рис. 3, ж). Они часто формируют сложно сросшиеся агрегаты, но в матрице роговиков нередко диагностируются и хорошо оформленные отдельные призматические кристаллы. В более удалённых от зоны контакта породах количество кальцита резко сокращается. Кальцит содержит очень низкие примеси $\mathrm{Fe}(0,1-0,3 \%), \mathrm{Mn}(0,2-0,3 \%)$, $\mathrm{Mg}(<0,1 \%)$ и практически не содержит $\mathrm{F}, \mathrm{Cl}$ и $\mathrm{S}$.

Эпидот-клиноцоизит $\quad\left(\mathrm{Ca}_{1,98} \quad\left(\mathrm{Al}_{2,65}, \quad \mathrm{Fe}_{0,31}\right)_{2,96}\right.$ $\left(\mathrm{Si}_{2,03} \mathrm{O}_{7}\right)\left(\mathrm{SiO}_{4}\right) \mathrm{O}(\mathrm{OH})$, усреднённая формула рассчитана по 6 ан.) встречается обычно внутри кварцкарбонатных жил в виде идиоморфных длиннопризматических кристаллов длиной до 1,5 мм. В эпидоте определены низкие концентрации галогенов (F 0,03$0,2 \%, \mathrm{Cl} 0,001-0,007 \%)$ и серы $(\mathrm{S} \leq 0,01 \%)$.

Anатит встречается с одинаковой частотой в породах зон ближнего и дальнего экзоконтакта, образуя призматические (рис. 4, з) или ксеноморфные (рис. 4, o) кристаллы размером до 0,1-0,3 мм. В изученных образцах встречены два типа апатита: 1) фтористый (F 2-5,5 \%, Cl<0,1\%); 2) условно хлористый $(\mathrm{Cl} 0,44-0,68 \%, \mathrm{~F}<0,1 \%)$. Оба типа характеризуются низким содержанием серы - <0,01\%.

В исследуемых экзоконтактовых породах были изучены сульфидные минераль - халькопирит, пирит, пирротин и пентландит, а также впервые была обнаружена Co-Pd-Ag и REE минерализация. Сульфиды, сульфоарсениды и теллуриды образуют парагенетическую ассоциацию и тесно связаны с кальцитовыми жилами зоны ближнего экзоконтакта. Кварцевые жилы Qz 2 зоны дальнего экзоконтакта, в особенности в местах пересечения ими FCQ жил, содержат относительно крупные (до 1,2 мм) зёрна лимонитизированных (гематит+гётит) сульфидов (рис. 2, б). В таких пластинчатых и жеодовых агрегатах (рис. 4, $a$, б), помимо остаточных примесей $\mathrm{Cu}(0,7-3,6 \%)$ и $\mathrm{Ni}$ $(0,3-0,7 \%)$, были обнаружены содержания $\mathrm{Rh}$ (до $0,03 \%)$ и $\mathrm{Pd}$ (до 0,17-0,32\%).

Халькопирит - самый распространённый сульфидный минерал, образующий вытянутые вдоль кальцитовых жил выделения размером до нескольких сантиметров (рис. 2, г). Также он образует самостоятельные или в срастании с пиритом, пирротином, кобальтином-герсдорфитом жиловидные вкрапления среди зёрен полевых шпатов и хлорита в роговиках (рис. $4,6, \partial, \kappa)$. В халькопирите отмечаются примеси $\mathrm{Zn}$ (до $0,05 \%$ ) и $\mathrm{Ni}$ (до 0,02\%).

Пирротин представлен мелкими амёбовидными вкраплениями в силикатной матрице роговиков (рис. $4,8,2$ ), часто находится в срастании с халькопиритом. В пирротине всегда присутствует примесь $\mathrm{Ni}$ от 0,42 до $1,05 \%$.

Пирит встречается в ассоциации с другими сульфидами как в связи с карбонатными жилами, так и внутри кварцевых жил поздней генерации. В первом случае он представлен прожилковыми выделениями (рис. 4, $)$ ), во втором - микронными идиоморфными кристаллами (рис. $4, e$ ). Первому типу пирита свойственны низкие примеси $\mathrm{Ni}(0-0,18 \%)$, тогда во втором типе отмечаются повышенные концентрации $\mathrm{Ni}$ (1-2\%).

Пентландит в исследованных породах редок и представлен обычно мелкими зёрнами в срастании с другими сульфидами. Также встречаются и ламели менее никелистого пентландита в пирротине (рис. 4, в, г). В пентландите отмечается постоянная примесь кобальта: в зернистых выделениях его концентрация выше $(1,1-2,3 \%$ Co), чем в ламелях $(0,7-0,9 \%$ Co).

Галенит образует редкие микронные зёрна в кобальтине-герсдорфите, часто приурочиваясь к трещинам в нём (рис. $4, ж)$ и в халькопирите. В галените всегда отмечается примесь Se до 1,9\%.

Сульфоарсениды представлены твёрдыми растворами $(\mathrm{Co}, \mathrm{Ni}, \mathrm{Fe})-\mathrm{As}-\mathrm{S}$ состава (табл. 2), соответствуя непрерывной изоморфной смеси $\mathrm{Fe}-\mathrm{Ni}$-кобальтина $u$ $\mathrm{Fe}$-Co-герсдорфита (рис. 5) - CGSS (cobaltitegersdorffite solid solution). В изученных породах они часто встречаются в ассоциации с халькопиритом, но в виде достаточно мелких выделений (в пределах 5-100 мкм). Морфологически они образуют прожилковые или субидиморфные агрегаты (рис. 4, г, 3, м), но изредка встречаются и мелкие идиоморфные кристаллы (рис. 4, $u, \kappa)$. И в тех, и других выделениях была выявлена примесь Pd (до 0,44 \%), которая, возможно, обусловлена наличием сложно диагностируемых включений $\mathrm{Pd}$-содержащих минеральных фаз. В нескольких анализах вместе с палладием определялась сурьма (0,34-0,41 \%), что может свидетельствовать о нахождении в CGSS мельчайших зёрен садбериита (PdSb). Также в некоторых выделениях CGSS была обнаружена примесь Rh (0,04-0,22 \%), которая также, возможно, связана с наличием наноразмерных включений родиевой минеральной фазы. B CGSS также выявлена примесь Те (до 0,02 \%) (табл. 2). 


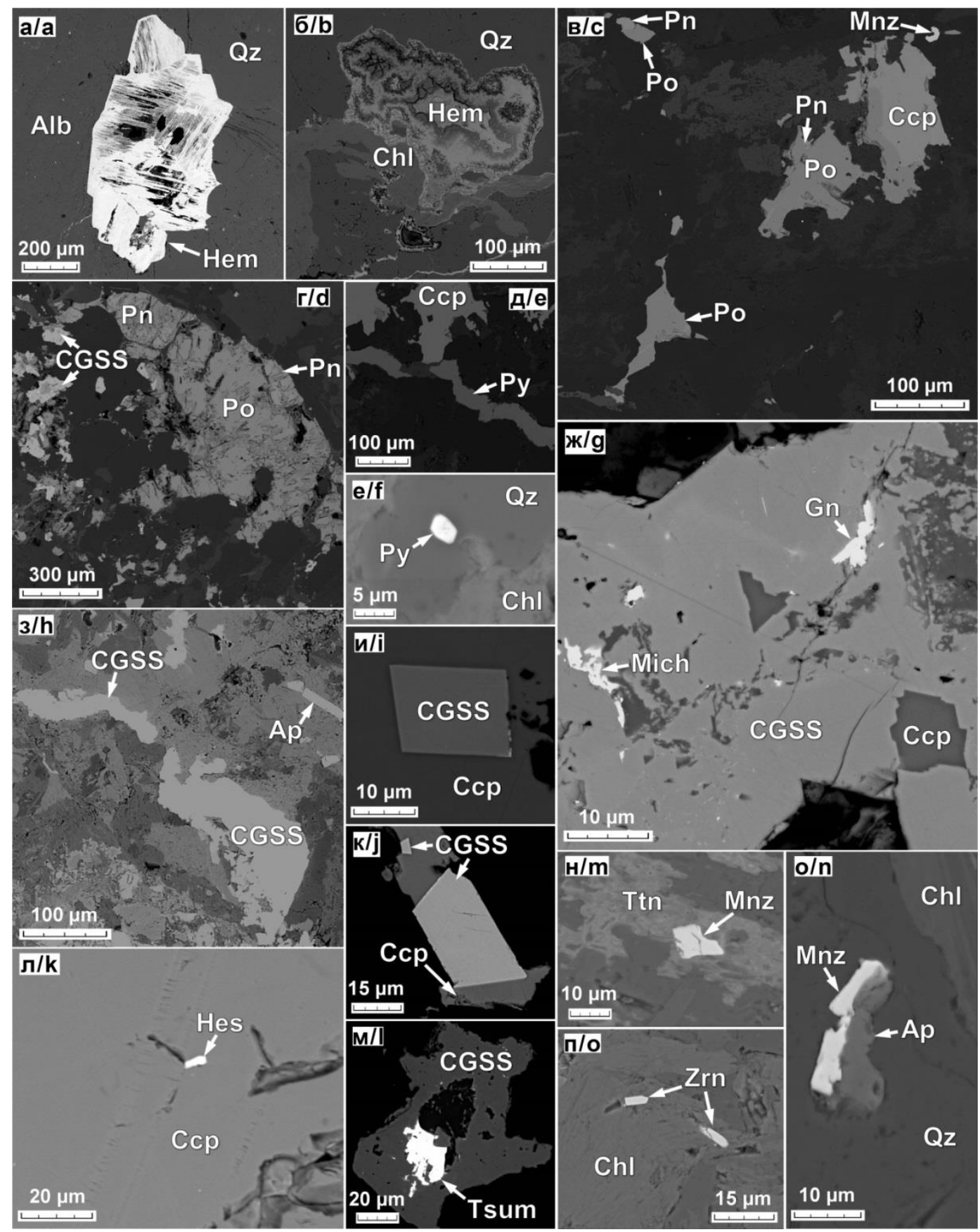

Puc. 4. Сульфидная, Co-Pd-Ag и Th-REE минерализачия экзоконтактовых пород массива Ташль-Tay (BSEизображения): а) зерно гематита с пластинчатой структурой; б) колломорфное выделение гематита; в) ксеноморфные выделения халькопирита (Сср), пирротина (Ро), пентландита (Pn) и зерно монацита (Мnz); г) ксеноморфные выделения пирротина, пентландита и кобальтин-герсдорфитового твёрдого раствора (CGSS); д) жильные выделения халькопирита и пирита (Py); е) зерно пирита; ж) включения майчнерита (Mich) и галенита (Gn) в CGSS; з) жильное выделение CGSS и кристалл апатита (Ap); и, к) идиоформные зёрна CGSS; л) зерно гессита (Hеs); м) корродированный кристалл иумоита (Tsum); н) зерно монацита в ассоциации с титанитом (Ttn); о) совместное срастание монацита и апатита; n) зёрна циркона в ассоциации с хлоритом. Обозначения других минералов расшифрованы в подписи к рис. 3

Fig. 4. Sulfide, Co-Pd-Ag and Th-REE mineralization from exocontact rocks of Tashly-Tau massif (BSE-images): a) hematite grain with lamellar structure; b) colloform hematite aggregate; c) anhedral chalcopyrite (Ccp), pyrrothite $(P o)$, pentlandite $(\mathrm{Pn})$ segregation and monazite $(\mathrm{Mnz})$ grain; $d)$ anhedral pyrrothite, pentlandite grains and cobaltite-gersdorffite solid solution (CGSS); e) veined chalcopyrite and pyrite (Py); f) pyrite grain; g) michenerite (Mich) and galena (Gn) inclusions in CGSS; $h$ ) veined CGSS aggregate and apatite crystal (Ap); $i, j)$ euhedral CGSS grains; $k$ ) hessite (Hes) grain; l) tsumoite (Tsum) corroded crystal; $m$ ) monazite grain associated with titanite (Ttn); n) intergrowth of monazite and apatite; o) zircon grains associated with chlorite. Other mineral abbreviations see in Fig. 3 caption 
Таблица 2. Представительные анализы сульфоарсенидов (CGSS) из экзоконтактовых пород массива Ташль-Тау

Table 2. Representative analyses of sulfoarsenides (CGSS) from exocontact rocks of Tashly-Tau massif

\begin{tabular}{|c|c|c|c|c|c|c|c|c|c|c|c|}
\hline $\begin{array}{c}\text { № ח/п } \\
\text { No. }\end{array}$ & $\begin{array}{l}\text { № пробоанализа } \\
\text { Microprobe no. }\end{array}$ & $\mathrm{Fe}$ & Co & $\mathrm{Ni}$ & $\mathrm{Pd}$ & $\mathrm{Sb}$ & $\mathrm{Te}$ & As & $\mathrm{S}$ & Total & $\begin{array}{l}\text { Кристаллохимическая формула } \\
\text { (в пересчёте на } 3 \text { ат. ед.) } \\
\text { Crystal chemical formula } \\
\text { (in terms of } 3 \text { a.u.) }\end{array}$ \\
\hline 1 & $3789^{-1-3}$ & 7,03 & 12,16 & 16,28 & - & - & - & 45,64 & 18,88 & 99,99 & $\left(\mathrm{Ni}_{0,46}, \mathrm{Co}_{0,34}, \mathrm{Fe}_{0,21}\right)_{1,01} \mathrm{As}_{1,01} \mathrm{~S}_{0,98}$ \\
\hline 2 & $3789^{-1-4}$ & 6,77 & 14,36 & 14,25 & - & - & - & 45,71 & 18,92 & 100,01 & $\left(\mathrm{Co}_{0,40}, \mathrm{Ni}_{0,40}, \mathrm{Fe}_{0,20}\right)_{1,01} \mathrm{As}_{1,01} \mathrm{~S}_{0,98}$ \\
\hline 3 & $3789^{-1-5}$ & 6,58 & 17,26 & 10,90 & - & - & - & 44,71 & 18,62 & 98,07 & $\left(\mathrm{Co}_{0,50}, \mathrm{Ni}_{0,31}, \mathrm{Fe}_{0,20}\right)_{1,01} \mathrm{As}_{1,01} \mathrm{~S}_{0.98}$ \\
\hline 4 & $3789^{-3-21}$ & 5,70 & 19,32 & 9,78 & - & - & - & 45,51 & 19,49 & 99,81 & $\left(\mathrm{Co}_{0,54}, \mathrm{Ni}_{0,28}, \mathrm{Fe}_{0,17}\right)_{0,99} \mathrm{As}_{1,01} \mathrm{~S}_{1,01}$ \\
\hline 5 & $3789^{-3-22}$ & 5,68 & 18,93 & 10,21 & - & - & - & 45,56 & 19,43 & 99,82 & $\left(\mathrm{Co}_{0,53}, \mathrm{Ni}_{0,29}, \mathrm{Fe}_{0,17}\right)_{0,99} \mathrm{As}_{1,01} \mathrm{~S}_{1,00}$ \\
\hline 6 & $3789^{-3-23}$ & 5,93 & 16,92 & 12,05 & - & - & - & 45,59 & 19,30 & 99,79 & $\left(\mathrm{Co}_{0,48}, \mathrm{Ni}_{0,34}, \mathrm{Fe}_{0,18}\right)_{0,99} \mathrm{As}_{1,01} \mathrm{~S}_{1,00}$ \\
\hline 7 & $3789^{-3-24}$ & 5,95 & 17,55 & 11,50 & - & - & - & 45,62 & 19,24 & 99,86 & $\left(\mathrm{Co}_{0,49}, \mathrm{Ni}_{0,32}, \mathrm{Fe}_{0,18}\right)_{1,00} \mathrm{As}_{1,01} \mathrm{~S}_{0.99}$ \\
\hline 8 & $3789^{-3-32}$ & 5,84 & 17,22 & 11,97 & - & - & - & 45,52 & 19,28 & 99,84 & $\left(\mathrm{Co}_{0,48}, \mathrm{Ni}_{0,34}, \mathrm{Fe}_{0,17}\right)_{1,00} \mathrm{As}_{1,01} \mathrm{~S}_{1,00}$ \\
\hline 9 & $3789^{-3 a-33}$ & 6,09 & 18,16 & 11,09 & - & - & - & 45,13 & 19,36 & 99,83 & $\left(\mathrm{Co}_{0,51}, \mathrm{Ni}_{0,31}, \mathrm{Fe}_{0,18}\right)_{1,00} \mathrm{As}_{1,00} \mathrm{~S}_{1,00}$ \\
\hline 10 & $3789^{-3 a-34}$ & 6,32 & 9,88 & 18,46 & 0,44 & - & - & 46,29 & 18,53 & 99,92 & $\left(\mathrm{Ni}_{0.53}, \mathrm{Co}_{0.28}, \mathrm{Fe}_{0,19}\right)_{1,00} \mathrm{As}_{1,03} \mathrm{~S}_{0.97}$ \\
\hline 11 & $3789^{-3 a-40}$ & 4,66 & 6,36 & 23,66 & 0,38 & 0,41 & - & 46,71 & 17,78 & 99,96 & $\left(\mathrm{Ni}_{0,68}, \mathrm{Co}_{0,18}, \mathrm{Fe}_{0,14}\right)_{1,01} \mathrm{As}_{1,05} \mathrm{~S}_{0,94}$ \\
\hline 12 & $3789^{-3 a-41}$ & 6,23 & 16,99 & 12,15 & - & - & - & 45,46 & 19,06 & 99,89 & $\left(\mathrm{Co}_{0,48}, \mathrm{Ni}_{0,34}, \mathrm{Fe}_{0,19}\right)_{1,01} \mathrm{As}_{1,01} \mathrm{~S}_{0,99}$ \\
\hline 13 & $3789^{-3 b-45}$ & 6,10 & 16,19 & 12,49 & - & - & - & 45,89 & 19,20 & 99,87 & $\left(\mathrm{Co}_{0,46}, \mathrm{Ni}_{0,35}, \mathrm{Fe}_{0,18}\right)_{0,99} \mathrm{As}_{1,02} \mathrm{~S}_{0,99}$ \\
\hline 14 & $3789^{-3 b-46}$ & 6,74 & 7,00 & 20,57 & $\begin{array}{l}- \\
\end{array}$ & - & - & 47,23 & 18,32 & 99,85 & $\left(\mathrm{Ni}_{0,59}, \mathrm{Co}_{0,20}, \mathrm{Fe}_{0,20}\right)_{0,99} \mathrm{As}_{1,05} \mathrm{~S}_{0,96}$ \\
\hline 15 & $3789^{-3 c-47}$ & 5,05 & 8,55 & 20,34 & 0,28 & - & - & 47,35 & 18,20 & 99,77 & $\left(\mathrm{Ni}_{0,58}, \mathrm{Co}_{0,24}, \mathrm{Fe}_{0,15}\right)_{0,98} \mathrm{As}_{1,06} \mathrm{~S}_{0,96}$ \\
\hline 16 & $3789^{-3 c-52}$ & 8,18 & 8,83 & 17,31 & 0,40 & - & - & 43,67 & 20,13 & 98,52 & $\left(\mathrm{Ni}_{0,49}, \mathrm{Co}_{0,25}, \mathrm{Fe}_{0,24}\right)_{0,98} \mathrm{As}_{0,97} \mathrm{~S}_{1,05}$ \\
\hline 17 & $3789^{-4 a-53}$ & 5,49 & 9,22 & 19,51 & 0,41 & 0,34 & - & 46,33 & 17,70 & 99,01 & $\left(\mathrm{Ni}_{0,57}, \mathrm{Co}_{0,27}, \mathrm{Fe}_{0,17}\right)_{1,00} \mathrm{As}_{1,06} \mathrm{~S}_{0,94}$ \\
\hline 18 & $3789^{-4 a-54}$ & 6,17 & 13,10 & 15,09 & - & - & - & 45,48 & 18,51 & 98,35 & $\left(\mathrm{Ni}_{0,43}, \mathrm{Co}_{0,38}, \mathrm{Fe}_{0,19}\right)_{1,00} \mathrm{As}_{1,03} \mathrm{~S}_{0,98}$ \\
\hline 19 & $3789^{-4 a-55}$ & 5,89 & 10,33 & 17,53 & - & - & - & 44,73 & 18,51 & 96,99 & $\left(\mathrm{Ni}_{0,51}, \mathrm{Co}_{0,30}, \mathrm{Fe}_{0,18}\right)_{0,99} \mathrm{As}_{1,02} \mathrm{~S}_{0,99}$ \\
\hline 20 & $3789^{-4 b-59}$ & 7,24 & 14,88 & 12,26 & - & - & - & 43,77 & 19,62 & 97,77 & $\left(\mathrm{Co}_{0,42}, \mathrm{Ni}_{0,35}, \mathrm{Fe}_{0,22}\right)_{0,99} \mathrm{As}_{0,98} \mathrm{~S}_{1,03}$ \\
\hline 21 & $3789^{-4 b-60}$ & 5,72 & 16,19 & 13,09 & - & - & - & 45,61 & 18,95 & 99,57 & $\left(\mathrm{Co}_{0,46}, \mathrm{Ni}_{0,37}, \mathrm{Fe}_{0,17}\right)_{1,00} \mathrm{As}_{1,01} \mathrm{~S}_{0,99}$ \\
\hline 22 & $3789^{-4 b-61}$ & 5,72 & 15,05 & 14,27 & - & - & - & 45,65 & 18,96 & 99,64 & $\left(\mathrm{Co}_{0,43}, \mathrm{Ni}_{0,40}, \mathrm{Fe}_{0,17}\right)_{1,00} \mathrm{As}_{1,01} \mathrm{~S}_{0,98}$ \\
\hline 23 & $3789^{-2-4}$ & 6,62 & 17,27 & 11,68 & $-1-$ & 0,03 & 0,02 & 44,87 & 19,34 & 100,21 & $\left(\mathrm{Co}_{0,48}, \mathrm{Ni}_{0,33}, \mathrm{Fe}_{0,20}\right)_{1,01} \mathrm{As}_{0,99} \mathrm{~S}_{1,00}$ \\
\hline 24 & $3789^{-2-5}$ & 5,05 & 21,67 & 8,74 & $-/-$ & 0,01 & 0,00 & 44,47 & 19,24 & 99,58 & $\left(\mathrm{Co}_{0,61}, \mathrm{Ni}_{0,25}, \mathrm{Fe}_{0,15}\right)_{1,01} \mathrm{As}_{0,99} \mathrm{~S}_{1,00}$ \\
\hline 25 & $3789^{-2-6}$ & 5,43 & 21,39 & 8,54 & $-/-$ & 0,01 & 0,01 & 45,05 & 19,21 & 100,52 & $\left(\mathrm{Co}_{0,60}, \mathrm{Ni}_{0,24}, \mathrm{Fe}_{0,16}\right)_{1,01} \mathrm{As}_{1,00} \mathrm{~S}_{0,99}$ \\
\hline 26 & $3789^{-2-8}$ & 5,43 & 20,52 & 8,87 & $-1-$ & 0,01 & 0,00 & 45,94 & 19,18 & 100,50 & $\left(\mathrm{Co}_{0,58}, \mathrm{Ni}_{0,25}, \mathrm{Fe}_{0,16}\right)_{0,99} \mathrm{As}_{1,02} \mathrm{~S}_{0,99}$ \\
\hline 27 & $3789^{-2-15}$ & 6,18 & 16,44 & 13,11 & $-1-$ & 0,07 & 0,02 & 47,66 & 19,31 & 102,82 & $\left(\mathrm{Co}_{0,45}, \mathrm{Ni}_{0,36}, \mathrm{Fe}_{0,18}\right)_{0,99} \mathrm{As}_{1,03} \mathrm{~S}_{0,98}$ \\
\hline
\end{tabular}

Примечание: 1-22 - анализы ЭДС, Tescan Vega3; 23-27 - анализы ВДС, JEOL JXA-8230; «-» - ниже предела обнаружения, «-/-»-не определялось

Note: 1-22 - EDS analyses, Tescan Vega3; 23-27 - WDS analyses, JEOL JXA-8230; «-» - below the detection limit, «-/-»not measured

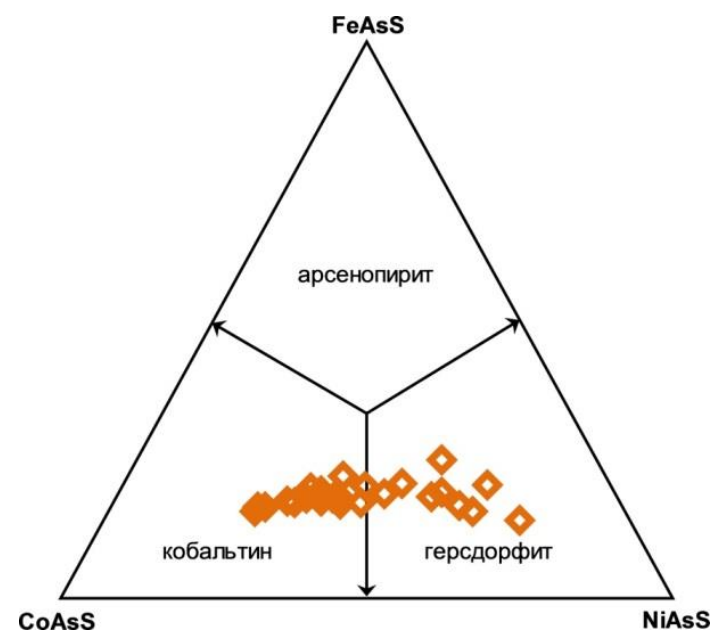

Puc. 5. Диаграмма FeAsS-CoAsS-NiAsS для сульфоарсенидов из экзоконтактовых пород массива Ташль-Tay

Fig. 5. FeAsS-CoAsS-NiAsS diagram for sulfoarsenides from exocontact rocks of Tashly-Tau massif

Теллуриды образуют микронные включения внутри сульфидных и сульфоарсенидных минералов. Наиболее часто были встречены теллуриды серебра (гессит $\mathrm{Ag}_{2} \mathrm{Te}$ ) и висмута (цумоит ВіТе). Из минералов платиновой группы был обнаружен сурьмяни- стый майчнерит $(\mathrm{Pd}(\mathrm{Bi}, \mathrm{Sb}) \mathrm{Te})$. Помимо гессита нами обнаружены недиагностируемые (<1 мкм) Agсодержащие минеральные фазы в срастании с монацитом.

Гессит образует призматические зёрна и найден исключительно внутри халькопирита (рис. 4, л). В гессите часто присутствует примесь $\mathrm{Pb}$ (до 2,95-5,71 \%) и иногда $\mathrm{Cd}(0,73-0,84 \%)$.

Цумоит представлен скелетными кристаллами, локализованными вблизи трещин и зон растворения кобальтина (рис. 4, м). Цумоит содержит примеси $\mathrm{Pb}$ (до $11 \%)$, Fe (0,50-0,65\%), Co (0,34-0,48\%), Ni $(0,73-1,11 \%)$.

Майчнерит встречен в кобальтине в виде скелетных кристаллов (рис. 4, ж), несущих, вероятно, следы растворения гидротермальным флюидом. Содержание $\mathrm{Sb}$ составляет 10,07-10,83 \%. Кристаллохимическая формула майчнерита рассчитана по 4 анализам (3 ат. ед.): $\mathrm{Pd}_{0,99}\left(\mathrm{Bi}_{0,61}, \mathrm{Sb}_{0,38}\right)_{0,99} \mathrm{Te}_{1,02}$. Ранее нами было показано, что сурьмянистые майчнериты из сульфидных руд интрузий худолазовского комплекса, предположительно, были образованы в гидротермальную стадию, тогда как первично магматический майчнерит является бессурьмянистым [4].

Ториево-редкоземельная минерализация пород экзоконтакта массива Ташлы-Тау представлена минералами группы монацита. Также в роговиках обнаруже- 
ны редкие и очень мелкие зёрна новообразованного циркона.

Монацит образует призматические (рис. $4, \mu$ ) или скелетные кристаллы размером от 1-2 до 20-30 мкм, локализованные в FCQ и Qz жилах, часто в срастании с апатитом (рис. 4, o). Химический состав минерала отражает наличие разных изоморфных членов ряда монацит (Ce, $\left.\mathrm{La}, \mathrm{Nd} . .).\left[\mathrm{PO}_{4}\right]\right)$ - чералит $\left(\mathrm{CaTh}\left[\mathrm{PO}_{4}\right]_{2}\right)$ - хаттонит $(\mathrm{Th}[\mathrm{SiO} 4])[10,11]$. Большая часть представительных анализов (обычно более крупные зёрна) соответствует собственно монациту (табл. 3) со средней эмпирической формулой (REE, $\mathrm{Ca}, \mathrm{Th})_{1,06}(\mathrm{P}, \mathrm{Si})_{0,94} \mathrm{O}_{4}$. Также встречаются многочисленные мелкие зёрна, ближе отвечающие по составу хаттониту (анализ № 1, табл. 3). Рентгеноспектральный анализ таких зёрен невозможно провести без захвата матрицы (кварца, полевых шпатов, хлорита и др.).

Таблица 3. Представительные анализы минералов группы монацита из экзоконтактовых пород массива Ташль-Тау

Table 3. Representative analyses of monazite group minerals from exocontaxt rocks of Tashly-Tau massif

\begin{tabular}{|c|c|c|c|c|c|c|c|c|c|c|c|c|c|c|c|}
\hline $\begin{array}{c}\text { № п/п } \\
\text { No. }\end{array}$ & $\begin{array}{c}\text { № пробоанализа } \\
\text { Microprobe No. }\end{array}$ & $\mathrm{SiO}_{2}$ & $\mathrm{P}_{2} \mathrm{O}_{5}$ & $\mathrm{CaO}$ & $\mathrm{FeO}$ & $\mathrm{SrO}$ & $\mathrm{Y}_{2} \mathrm{O}_{3}$ & $\mathrm{La}_{2} \mathrm{O}_{3}$ & $\mathrm{Ce}_{2} \mathrm{O}_{3}$ & $\mathrm{Pr}_{2} \mathrm{O}_{3}$ & $\mathrm{Nd}_{2} \mathrm{O}_{3}$ & $\mathrm{Sm}_{2} \mathrm{O}_{3}$ & $\mathrm{Gd}_{2} \mathrm{O}_{3}$ & $\mathrm{ThO}_{2}$ & Total \\
\hline 1 & $\mathrm{~K}_{18}-113 b^{-34}$ & 7,66 & 19,28 & 5,40 & 1,72 & - & - & 2,65 & 3,57 & - & 3,02 & - & - & 56,42 & 99,72 \\
\hline 2 & $\mathrm{~K}_{18}-113 b^{-63}$ & 1,21 & 32,18 & 1,33 & - & 1,29 & 1,36 & 13,90 & 29,04 & 3,33 & 11,79 & 2,49 & 1,09 & - & 99,00 \\
\hline 3 & $\mathrm{~K}_{18}-113 b^{-64}$ & - & 32,33 & 1,23 & - & 1,68 & - & 15,19 & 29,77 & 2,85 & 11,85 & - & - & 3,75 & 98,64 \\
\hline 4 & $\mathrm{~K}_{18}-113 b^{-65}$ & 4,01 & 30,73 & 1,24 & - & 1,13 & 2,91 & 13,94 & 26,72 & 2,45 & 11,18 & - & - & 4,08 & 98,39 \\
\hline 5 & $\mathrm{~K}_{18}-113 b^{-66}$ & 0,77 & 33,00 & 1,96 & - & 1,22 & - & 16,14 & 31,17 & 3,51 & 12,21 & - & - & - & 99,98 \\
\hline 6 & $\mathrm{~K}_{18}-113 b^{-67}$ & 1,39 & 33,29 & 1,37 & - & 1,69 & - & 15,71 & 29,99 & - & 11,41 & - & - & 5,16 & 100,01 \\
\hline 7 & $\mathrm{~K}_{18}-113 b^{-69}$ & 5,67 & 28,25 & 2,11 & - & - & 3,10 & 13,84 & 26,99 & 2,44 & 10,66 & - & - & 5,26 & 98,32 \\
\hline 8 & $\mathrm{~K}_{18}-113 b^{-70}$ & 1,33 & 33,26 & 1,35 & - & 1,40 & - & 15,89 & 30,40 & - & 12,44 & - & - & 3,92 & 99,99 \\
\hline 9 & $\mathrm{~K}_{18}-113 b^{-71}$ & - & 31,29 & 1,19 & - & 1,36 & - & 14,86 & 28,97 & 3,05 & 11,64 & 1,33 & 1,33 & 4,15 & 99,17 \\
\hline 10 & $\mathrm{~K}_{18}-113 b^{-72}$ & - & 31,95 & 1,44 & - & 1,33 & - & 16,43 & 30,90 & - & 12,09 & - & - & 5,03 & 99,18 \\
\hline 11 & $3789^{-1-6}$ & 0,92 & 30,06 & 0,97 & - & - & - & 15,21 & 29,32 & 3,11 & 11,87 & 1,79 & 0,98 & 3,99 & 98,22 \\
\hline
\end{tabular}

Кристаллохимические формулы монацитов были рассчитаны по стехиометрии на 4 атома кислорода (по данным табл. 3):

1. $\left(\mathrm{Th}_{0,54}, \mathrm{Ca}_{0,24}, \mathrm{Fe}_{0,07}, \mathrm{Ce}_{0,05}, \mathrm{La}_{0,04}, \mathrm{Nd}_{0,04}\right)_{0,99}\left(\mathrm{P}_{0,69}\right.$, $\left.\mathrm{Si}_{0,32}\right)_{1,01} \mathrm{O}_{4}$,

2. $\left(\mathrm{Ce}_{0,40}, \mathrm{La}_{0,19}, \mathrm{Nd}_{0,16}, \mathrm{Ca}_{0,05}, \mathrm{Pr}_{0,05}, \mathrm{Sm}_{0,03}, \mathrm{Sr}_{0,03}, \mathrm{Y}_{0,03}\right.$, $\left.\mathrm{Gd}_{0,01}\right)_{0,94}\left(\mathrm{P}_{1,01}, \mathrm{Si}_{0,04}\right)_{1,06} \mathrm{O}_{4}$,

3. $\left(\mathrm{Ce}_{0,42}, \mathrm{La}_{0,22}, \mathrm{Nd}_{0,16}, \mathrm{Ca}_{0,05}, \mathrm{Pr}_{0,04}, \mathrm{Sr}_{0,04}, \mathrm{Th}_{0,03}\right)_{0,96}$ $\mathrm{P}_{1,04} \mathrm{O}_{4}$

4. $\left(\mathrm{Ce}_{0,36}, \mathrm{La}_{0,19}, \mathrm{Nd}_{0,15}, \mathrm{Y}_{0,06}, \mathrm{Ca}_{0,05}, \mathrm{Th}_{0,03}, \operatorname{Pr}_{0,03}\right.$, $\left.\mathrm{Sr}_{0,02}\right)_{0,89}\left(\mathrm{P}_{0,96}, \mathrm{Si}_{0,15}\right)_{1,11} \mathrm{O}_{4}$,

5. $\left(\mathrm{Ce}_{0,42}, \mathrm{La}_{0,22}, \mathrm{Nd}_{0,16}, \mathrm{Ca}_{0,08}, \mathrm{Pr}_{0,05}, \mathrm{Sr}_{0,03}\right)_{0,95}\left(\mathrm{P}_{1,02}\right.$, $\left.\mathrm{Si}_{0,03}\right)_{1,05} \mathrm{O}_{4}$,

6. $\left(\mathrm{Ce}_{0,41}, \mathrm{La}_{0,21}, \mathrm{Nd}_{0,15}, \mathrm{Ca}_{0,05}, \mathrm{Th}_{0,04}, \mathrm{Sr}_{0,04}\right)_{0,91}\left(\mathrm{P}_{1,04}\right.$, $\left.\mathrm{Si}_{0,05}\right)_{1,09} \mathrm{O}_{4}$,

7. $\left(\mathrm{Ce}_{0,36}, \mathrm{La}_{0,19}, \mathrm{Nd}_{0,14}, \mathrm{Ca}_{0,08}, \mathrm{Y}_{0,06}, \mathrm{Pr}_{0,03}, \mathrm{Th}_{0,04}\right)_{0,91}$ $\left(\mathrm{P}_{0,88}, \mathrm{Si}_{0,21}\right)_{1,09} \mathrm{O}_{4}$

8. $\left(\mathrm{Ce}_{0,41}, \mathrm{La}_{0,22}, \mathrm{Nd}_{0,14}, \mathrm{Ca}_{0,05}, \mathrm{Th}_{0,03}, \mathrm{Sr}_{0,03}\right)_{0,91}\left(\mathrm{P}_{1,04}\right.$, $\left.\mathrm{Si}_{0,05}\right)_{1,09} \mathrm{O}_{4}$,

9. $\left(\mathrm{Ce}_{0,41}, \mathrm{La}_{0,21}, \mathrm{Nd}_{0,16}, \mathrm{Ca}_{0,05}, \mathrm{Pr}_{0,04}, \mathrm{Th}_{0,04}, \mathrm{Sr}_{0,03}\right.$, $\left.\mathrm{Sm}_{0,02}, \mathrm{Gd}_{0,02}\right)_{0,98} \mathrm{P}_{1,02} \mathrm{O}_{4}$

10. $\left(\mathrm{Ce}_{0,44}, \mathrm{La}_{0,23}, \mathrm{Nd}_{0,17}, \mathrm{Ca}_{0,06}, \mathrm{Th}_{0,04}, \mathrm{Sr}_{0,03}\right)_{0,97} \mathrm{P}_{1,03} \mathrm{O}_{4}$,

11. $\left(\mathrm{Ce}_{0,42}, \mathrm{La}_{0,22}, \mathrm{Nd}_{0,17}, \mathrm{Pr}_{0,04}, \mathrm{Ca}_{0,04}, \mathrm{Th}_{0,04}, \mathrm{Sm}_{0,02}\right.$, $\left.\mathrm{Gd}_{0,01}\right)_{0,97}\left(\mathrm{P}_{1,00}, \mathrm{Si}_{0,04}\right)_{1,03} \mathrm{O}_{4}$

Циркон встречается в виде идиоморфных призматических кристаллов длиной до 10-20 мкм в серициткварц-хлоритовых роговиках и FCQ-жилах. Иногда зёрна циркона наблюдаются в участках совместно ориентированной структуры вместе с чешуйками хлорита (рис. 4, п).

\section{Условия образования сульфидно-кварц-карбонатных жил}

В кварце сульфидно-кварцевых жил из роговиков ближней экзоконтактовой зоны изучены сингенетичные двухфазные флюидные включения, локализованные в центральных частях зёрен и не имеющие видимой связи с трещинами в минерале (рис. 6, a). Они имеют размеры 10-12 мкм, овальную форму, редко с элементами кристаллографических граней. Газовые вакуоли занимают до 20 \% объёма во включении. Включения содержат растворы с температурами эвтектики $-22,8 \ldots-23,8$ и $-33 \ldots-33,9{ }^{\circ} \mathrm{C}$, что свидетельствует о присутствии во флюиде хлоридов $\mathrm{Na}, \mathrm{K}$, $\mathrm{Mg}$. Температуры гомогенизации включений в жидкую фазу составляют $320-370{ }^{\circ} \mathrm{C}$ с пиками значений на гистограмме, солёность варьирует от 8 до 10,6 мас. \% NaCl-экв. с пиками (рис. 6, в).
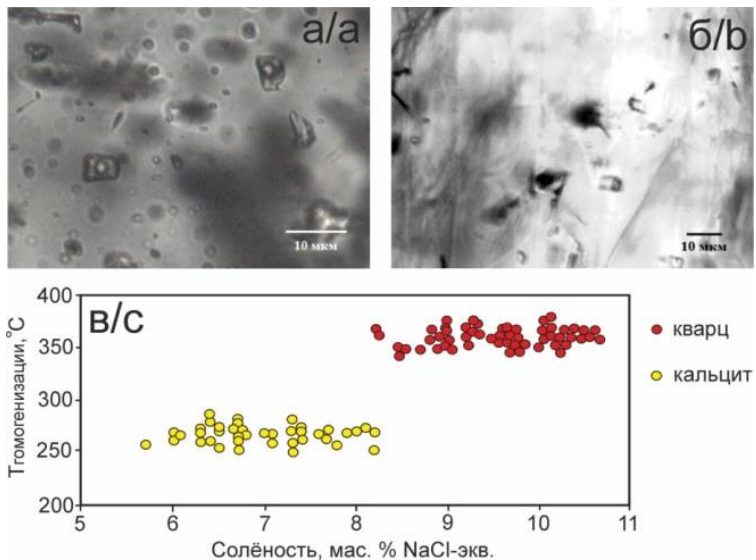

Pис. 6. Флюидные включения в минералах сульфидноквари-карбонатных жил: а) в кварие; б) в кальиите; в) соотношение температур гомогенизаияи и солености включений

Fig. 6. Fluid inclusions in minerals of sulfide-quartzcarbonate veins: a) in quartz; b) in calcite; c) temperature of homogenization vs. salinity plot for inclusions

Кальцит в сульфидно-кварц-карбонатных жилах образует изометричные прозрачные или полупрозрачные зёрна, прожилки или скрытокристаллические 
скопления с характерным двупреломлением. В нём также установлены сингенетичные двухфазные флюидные включения, которые расположены согласно направлениям спайности минерала (рис. 6, б). Включения имеют размер 10-15 мкм, изометричную, часто извилистую форму с отростками. Включения образуют группы (по 2-3) с близким соотношением фаз или одиночные включения в центральных частях зёрен кальцита. Газовая вакуоль занимает до 20 \% объёма включения. Согласно полученным температурам эвтектики от $-31,9$ до $-33,9{ }^{\circ} \mathrm{C}$, флюид содержит хлориды $\mathrm{Mg}$ и $\mathrm{Na}$. Солёность варьирует от 6 до 8 мас. \% $\mathrm{NaCl}$-экв. с пиком. Включения гомогенизировались в жидкую фазу при температурах $250-280^{\circ} \mathrm{C}$ с пиком (рис. 6,8$)$.

В кварце и кальците были также обнаружены двухфазные вторичные включения, трассирующие мелкие трещины в минералах и имеющие размеры менее 5 мкм, а также однофазные водные включения размером до 5 мкм, которые ассоциируют с двухфазными первичными и псевдовторичными включениями

\section{Обсуждение результатов}

Результаты проведённых исследований показали, что сульфидная, сульфоарсенидная и теллуридная минерализация характерна для роговиков, непосредственно примыкающих к массиву Ташлы-Тау. Они отвечают наиболее высокотемпературной стадии контактово-метаморфических процессов. Рассеянная ThREE-минерализация развита в метапесчаниках несколько более удалённой экзоконтактовой зоны, а минералы S, As, Те здесь не выявлены, лишь изредка встречается мелкодисперсный пирит. Однако в кварцевых жилах второй генерации $\left(\mathrm{Qz}_{2}\right)$ обнаружены минералы-гидроксиды железа, содержащие примеси $\mathrm{Cu}, \mathrm{Ni}, \mathrm{S}, \mathrm{As}, \mathrm{Pd}$, что свидетельствует о раннем существовании сульфидных, сульфоарсенидных минералов, прежде чем они были замещены. Таким образом, этот факт может отражать наличие резких изменений некоторых условий среды минералообразования.

В исследуемых породах новообразованные гидроксилсодержащие минералы - хлорит, апатит-1, клиноцоизит - обеднены хлором $(\mathrm{Cl}<0,1 \%)$ и серой $(\mathrm{S}<0,01 \%)$. На основе этих данных можно полагать, что активность хлора в гидротермальном флюиде была низкой (по крайней мере, на ранней стадии), а сера находилась в форме бисульфид-иона $\left(\mathrm{HS}^{-}\right)$и она главным образом была затрачена на формирование первичных сульфидных и сульфоарсенидных минералов. Позднее, судя по формированию минеральных ассоциаций, равновесных с окисленной средой [12], произошло возрастание активности хлора. Одним из чутких индикаторов условий минералообразующей (в том числе рудообразующей) среды является состав апатита [13]. Предпринятыми исследованиями минералогии экзоконтактовых пород массива Ташлы-Тау предварительно установлено, что фтористый апатит ассоциирует с более ранними по времени формирования сульфидными минералами (Ni-содержащий пирит, халькопирит), а хлористый апатит образует парагенетическую связь с монацитом, предположительно кристаллизовавшимся позднее. Это хорошо согласуется с известным фактом о лучшей растворимости сульфидов в присутствии хлора [14]. Таким образом, можно констатировать, во-первых, существование двух генераций апатита - фтористой (ранней) и хлористой (поздней), а во-вторых, выявить различие в составе гидротермального флюида на ранней и поздней рудообразующих стадиях.

Для оценки РТ-условий кристаллизации новообразованных силикатных минеральных фаз был использован хлоритовый геотермобарометр. Расчёты были выполнены по методике [15], развивающей ранее опубликованные методы М. Кателино и Э. Джоветта и основанной на модели смешивания в системе $\mathrm{MgO}-$ $\mathrm{FeO}-\mathrm{Al}_{2} \mathrm{O}_{3}-\mathrm{SiO}_{2}-\mathrm{H}_{2} \mathrm{O}$ среди конечных членов (амезита, клинохлора, дафнита и судоита). Для расчётов использовались анализы чешуйчатых кристаллов хлорита из основной массы приконтактовых роговиков, а также FCQ и Qz 2 жил. Получено 11 пар значений температура-давление, которые укладываются в диапазон $183-235^{\circ} \mathrm{C}$ и 6,7-8,1 кбар (среднее $208^{\circ} \mathrm{C}$ и 7,4 кбар).

Рудная минерализация пород массива Ташлы-Тау представлена пирротином (60-90\%), халькопиритом (10-20\%) и пентландитом (5-10\%). В незначительном объёме встречаются сфалерит, галенит, кобальтин и минералы элементов платиновой группы - Sbмайчнерит и сперрилит [3]. Таким образом, минеральный состав рудной ассоциации пород самого массива и ближней экзоконтактовой зоны сходен и отличается главным образом лишь соотношениями самих рудных минералов. Более того, составы сульфидных минералов экзоконтактовой зоны очень близки к составам первично-магматических сульфидов в габброидах (по уровню концентраций Ni в пирротине, Со в пентландите). В рудах роговиков, как и в габброидах, тоже можно выделить две генерации пентландита: 1) зернистый высоконикелистый в сростках; 2) пламевидный низконикелистый в ламелях распада моносульфидного твёрдого раствора. Ранее нами было показано, что изменённые первичные или переотложенные вторичные сульфидные фазы существенно различаются по составу примесных элементов [4]. Это даёт основание для предположения о наличии процесса миграции сульфидного расплава из кристаллизующегося интрузивного массива во вмещающие породы по трещинам [16]. В роговиках пирротин имеет подчинённое значение при преобладании халькопирита и существенном количестве минералов кобальтингерсдорфитового ряда. Составы майчнерита из габброидов и роговиков очень близки и характеризуются значительной примесью $\mathrm{Sb}(11,07-12,35 \%)$. Однако в кобальтинах из сульфидных руд массива ранее не была определена примесь Pd. Природа примеси Pd в сульфоарсенидах экзоконтактовых пород недостаточно ясна. С одной стороны, в ряде случаев в BSE-режиме электронного микроскопа различаются наноразмерные включения Pd-содержащих фаз в CGSS, а с другой - такие включения часто не видны и намечается тенденция, выражающаяся в контроле концентрации палладия содержанием никеля. В большинстве случаев палладий определяется 
в тех CGSS, которые обогащены герсдорфитовым миналом (NiAsS). На рис. 7 представлен характер распределения $\mathrm{Pd}$ в зависимости от концентраций $\mathrm{Fe}$, Co и $\mathrm{Ni}$ в CGSS. B паре Ni-Pd наблюдается достаточно отчётливая положительная корреляция, тогда как в парах $\mathrm{Fe}-\mathrm{Pd}$ и Сo-Pd она слабая отрицательная. Известно, что среди этих элементов палладий наиболее близок по свойствам к никелю, что выражается в развитии изоморфизма в системе $\mathrm{Pd}-\mathrm{Ni}[17,18]$.

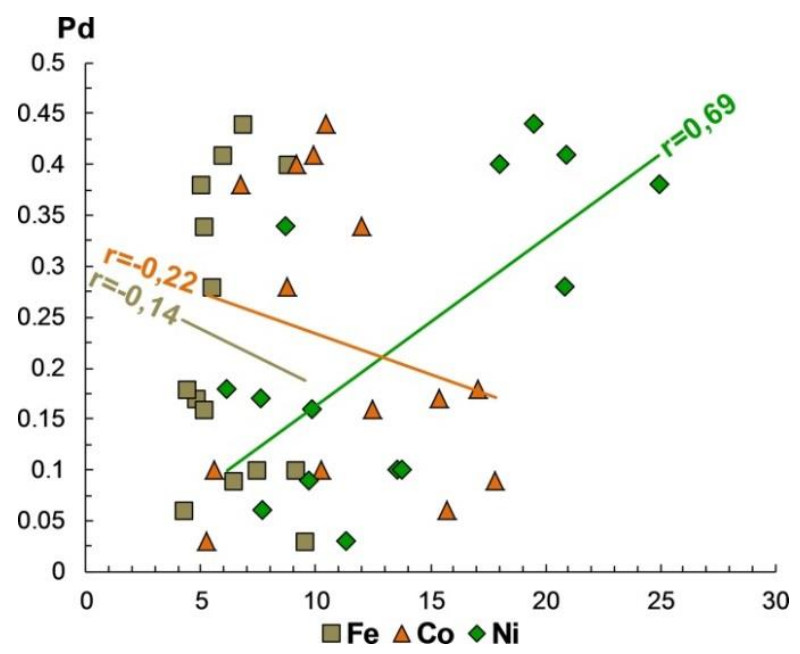

Pис. 7. Диаграмма в координатах «Элемент (Fe, Co, $\mathrm{Ni})$ - Pd» для сульфоарсенидов из экзоконтактовых пород массива Ташль-Тау. Примечание: $r$ - коэффициент корреляции

Fig. 7. «Element (Fe, Co, Ni) - Pd» plot for sulfoarsenides from exocontact rocks of Tashly-Tau massif. Note: $r$ is the correlation coefficient

Вмещающие массив Ташлы-Тау неметаморфизованные породы биягодинской свиты обеднены халькофильными и сидерофильными элементами. В них также не выявлены сульфидные и сульфоарсенидные минералы. Таким образом, источником Co-Pd-Rh-Ag минерализации экзоконтактовых пород может являться лишь сам массив Ташлы-Тау, породы и руды которого были существенно переработаны на постмагматическом этапе [3]. Гидротермально-метасоматические изменения руд привели к широкому замещению пирротина пиритом и пентландита виоларитом. Пентландит является основным концентратором Со (до 3-4 \%). Гидротермальный флюид вызывал не только замещение первичных минералов вторичными, но и общее сокращение размеров сульфидных выделений, что неизбежно приводило к выносу халькофильных и сидерофильных элементов, являющихся достаточно мобильными при метасоматических процессах [19].

Источником Th-REE-минерализации, вероятно, являются сами терригенные породы биягодинской свиты. Песчаники в среднем в 3-5 раз больше обогащены Th и REE в сравнении с габброидами массива Ташлы-Тау. Торий и редкоземельные элементы, вероятно, при контактовом метаморфизме мобилизовались из глинистых минералов, формировавших цемент метапесчаников биягодинской свиты. Известно, что глинистые минералы могут являться концентра- торами и редкоземельных, и радиоактивных элементов [20-22].

По данным термобарогеохимических исследований сульфидно-кварцевые жилы отлагались в процессе остывания единого гидротермального раствора (флюида), имеющего комплексный $\mathrm{Na}-\mathrm{K}-\mathrm{Mg}$ хлоридный состав при температурах не менее 370-320 ${ }^{\circ} \mathrm{C}$, а более поздние сульфидно-кварцкарбонатные жилы - при 280-250 ${ }^{\circ} \mathrm{C}$. Солёность флюида также уменьшалась от 10,6 (сульфиднокварцевые жилы) до 6 мас. \% (сульфидно-кварцкарбонатные жилы). Это может быть связано с их смешением с флюидами метаморфических пород, часто сопровождающимся реакциями дегидратации флюида, либо с глубинными флюидами, продуцируемыми соседствующими подогретыми интрузиями. Узкий диапазон изменения температур и солёности растворов свидетельствует об относительно стабильных условиях минералообразования и/или незначительном поступлении новых порций гидротермального флюида в рудообразующую систему.

Полученные данные по Co-Pd-Ag минерализации экзоконтактовых пород массива Ташлы-Тау могут быть использованы в решении ряда вопросов, связанных с петрологией и рудной минерализацией других массивов худолазовского комплекса. В частности, в южной части массива Бускун-III авторами были обнаружены приконтактовые долеритовые дайки, также несущие Co-Ni-сульфоарсенидную и REE минерализацию. В этом массиве при бурении скважин не были вскрыты рудные тела, что послужило поводом считать его бесперспективным [Бучковский и др., 1974ф], однако новые минералогические данные, представленные в настоящей статье, могут служить одним из критериев, указывающих на потенциальную продуктивность массива Бускун-III.

\section{Заключение}

Результаты проведённых исследований позволяют сделать ряд основных выводов:

- внедрение габброидного массива Ташлы-Тау, представляющего собой шток, вызвало метаморфизацию вмещающих песчаников биягодинской свиты с образованием экзоконтактовой зоны роговиков мощностью от 1-3 до15-20 м;

- в зависимости от удалённости вмещающих пород от контакта с интрузивным телом можно выделить зоны ближнего и дальнего экзоконтакта, отличающиеся степенью метаморфизации и метасоматизации пород;

- породы экзоконтактовой зоны прорваны многочисленными жилами кварцевого (ранней $-\mathrm{Qz}_{1}$ и поздней - $\mathrm{Qz}_{2}$ генерации), кварц-хлорит-полевошпатового (FCQ) и кварц-кальцитового состава, нередко образующими взаимные пересечения;

- кварц-карбонатные жилы, примыкающие к самому массиву Ташлы-Тау, содержат вкрапленную сульфидную и сульфоарсенидную минерализацию, вмещающие зёрна теллуридов $\mathrm{Pd}$ и $\mathrm{Ag}$; 
- сульфоарсенидная минерализация представлена изоморфной смесью Fe-Ni-кобальтина и Fe-Coгерсдорфита, содержащей примеси $\mathrm{Pd}$ до 0,44 \%;

- жилы $\mathrm{Qz}_{2}$ и FCQ содержат рассеянную Th-REE минерализацию, представленную мелкими зёрнами минералов группы монацита (твёрдые растворы тройной системы монацит-чералит-хаттонит);

- по данным термобарогеохимических исследований сульфидно-кварцевые жилы отлагались в процессе остывания единого гидротермального флюида $\mathrm{Na}-\mathrm{K}-\mathrm{Mg}$-хлоридного состава при температурах не менее $370-320^{\circ} \mathrm{C}$, более поздние сульфидно-кварц-карбонатные жилы - при $280-250{ }^{\circ} \mathrm{C}$;

\section{СПИСОК ЛИТЕРАТУРЫ}

1. Салихов Д.Н., Пшеничный Г.Н. Магматизм и оруденение зоны ранней консолидации Магнитогорской эвгеосинклинали. - Уфа: БФАН СССР, 1984. - 112 с.

2. First finds of platinum and palladium minerals in sulfide ores of the Khudolaz intrusive complex (Southern Urals) / I.R. Rakhimov, D.E. Saveliev, V.N. Puchkov, D.N. Salikhov, A.V. Vishnevskiy, A.G. Vladimirov // Doklady Earth Sciences. - 2018. - V. 479. Iss. 2. - P. 439-442

3. Минералогия пород и руд интрузии Ташлы-Тау Худолазовского комплекса / И.Р. Рахимов, А.В. Вишневский, Ш.Р. Зайлямов, А.В. Михеева // Геология. Известия отделения наук о Земле и природных ресурсов АН РБ. - 2018. - № 25. - С. 77-85.

4. Рахимов И.Р., Савельев Д.Е., Вишневский А.В. Сульфидноплатинометалльная минерализация изменённых габбро массива Малютка худолазовского комплекса: влияние гидротермальных процессов на тип минеральной ассоциации // Вестник Института геологии Коми НЦ УрО РАН. - 2019. - № 275. - С. 15-24.

5. Борисенко А.С. Анализ солевого состава растворов газовожидких включений в минералах методом криометрии. Использование методов термобарогеохимии при поисках и изучении рудных месторождений. - М/: Недра, 1982. - С. 37-46.

6. Bodnar R.J., Vityk M.O. Interpretation of microthermometric data for $\mathrm{H} 2 \mathrm{O}-\mathrm{NaCl}$ fluid inclusions. Fluid inclusions in minerals: methods and applications. Pontignana-Siena, 1994. - P. 117-130.

7. Маслов В.А., Артюшкова О.В. Стратиграфия и корреляция девонских отложений Магнитогорской мегазоны Южного Урала. - Уфа: ДизайнПолиграфСервис, 2010. - 288 с

8. Мельничук О.Ю., Фазлиахметов А.М. К вопросу о существовании микроконтинента в позднедевонское время на Среднем Урале. Проблемы минералогии, петрографии и металлогении. Научные чтения памяти П.Н. Чирвинского. № 20. - Пермь: Пермский госуниверситет, 2017. - С. 148-155.

9. Юдович Я.Э., Кетрис М.П. Основы литохимии. - СПб.: Наука, 2000. $-479 \mathrm{c}$.

10. Ковалёв С.Г., Тимофеева Е.А., Пиндюрина Е.О. Монацитовая минерализация западного склона Южного Урала // Геологический сборник № 8. Информационные материалы. - Уфа: ИГ УНЦ РАН, 2009. - С. 138-144.

11. Сингенетичные циркон, монацит, ксенотим и фторапатит апопикритовых флогопит-магнезитовых гумбеитов Берёзовского месторождения золота, Урал / Э.М. Спиридонов, И.М. Куликова, Н.В. Сидорова, Н.Н. Коротаева, А.Н. Трошкина // Новые данные о минералах. - 2013. - Вып. 48. - С. 37-56.

12. Mountain B.W., Wood S.A. Chemical controls on the solubility, transport, and deposition of platinum and palladium in
- источником Co-Pd-Rh-Ag минерализации являются гидротермально переработанные сульфидноплатинометальные руды массива Ташлы-Тау;

- источником Th-REE-минерализации могут быть породы биягодинской свиты.

Исследования выполнены при финансовой поддержке РФФИ (грант № 18-35-00391) и Государственного задания ИГ УФИЦ РАН по теме № 0252-2017-0012, а также в рамках госбюджетных исследований ИГГ УрО РАН по теме № 0393-2016-0020 (№ госрегистращии АAAA-A18118052590029-6). Термобарогеохимические исследования поддержаны государственным заданием ИМин ЮУ ФНЦ МиГ УрО РАН (2019-2021 г2.).

hydrothermal solutions: a thermodynamic approach // Economic geology. - 1988. - V. 83. - P. 492-510.

13. Холоднов В.В., Бушляков И.Н. Галогены в эндогенном рудообразовании. - Екатеринбург: УрО РАН, 2002. - 392 с.

14. Wood S.A., Mountain B.W. Thermodynamic constraints on the solubility of platinum and palladium in hydrothermal solutions: reassessment of hydroxide, bisulfide, and ammonia complexing // Economic geology. - 1989. - V. 84. - P. 2020-2028.

15. Lanari P., Wagner T., Vidal O. A thermodynamic model for ditrioctahedral chlorite from experimental and natural data in the system $\mathrm{MgO}-\mathrm{FeO}-\mathrm{Al} 2 \mathrm{O} 3-\mathrm{SiO} 2-\mathrm{H} 2 \mathrm{O}$ : applications to $\mathrm{P}-\mathrm{T}$ sections and geothermometry // Contributions to Mineralogy and Petrology. - 2014. - V. 167. - P. 268-287.

16. Вишневский А.В, Черданцева М. В. Раскристаллизованные капли сульфидного расплава из массива рудный в С-3 Монголии: модельный объект для изучения распределения и форм нахождения элементов-примесей при кристаллизации природных сульфидных жидкостей // VII Сибирская научнопрактическая конференция молодых ученых по наукам о Земле (с участием иностранных специалистов): Материалы конференции. - Новосибирск: ИГМ СО РАН, 2014. - С. 10-11.

17. Platinum-group element distribution in base-metal sulfides of the Merensky Reef from the eastern and western Bushveld Complex, South Africa / I. Osbahr, R. Klemd, T. Oberthür, H. Brätz, R. Schouwstra // Mineralium Deposita. - 2013. - V. 48. - Iss. 2. - P. 211-232.

18. Mineralogical siting of platinum-group elements in pentlandite from the Bushveld Complex, South Africa / M. Junge, R. Wirth, T. Oberthür, F. Melcher, A. Schreiber // Mineralium Deposita. 2015. - V. 50. - Iss. 1. - P. 41-54.

19. Low temperature alteration of magmatic Ni-Cu-PGE sulfides as a source for hydrothermal $\mathrm{Ni}$ and PGE ores: A quantitative approach using automated mineralogy / D.A. Holwell, A. Zeinab, L.A. Warda, D.J. Smith, S.D. Graham, I. McDonald, J.W. Smith // Ore Geology Reviews. - 2017. - V. 91. - P. 718-740.

20. Rare earth distributions in clay minerals and in the clay-sized fraction of the Lower Permian Havensville and Eskridge shales of Kansas and Oklahoma / R.L. Cullers, S. Chaudhuri, B. Arnold, M. Lee, C. Wolf Jr.// Geochimica et Cosmochimica Acta. 1975. - V. 39. - Iss. 12. - P. 1691-1703.

21. REE distribution in the clay fraction of pelites from the southern Apennines, Italy / A. Caggianelli, S. Fiore, G. Mongelli, A. Salvemini // Chemical Geology. - 1992. - V. 99. - Iss. 4. - P. 253-263.

22. Григорьев Н.А. Распределение химических элементов в верхней части континентальной коры. - Екатеринбург: Уро РАН, 2009. -382 c.

Поступила 17.06.2020 2.

\section{Информация об авторах}

Рахимов И.Р., кандидат геолого-минералогических наук, старший научный сотрудник лаборатории магматизма и метаморфизма Института геологии УФИЦ РАН.

Анкушева Н.Н., кандидат геолого-минералогических наук, научный сотрудник лаборатории минералогии рудогенеза Института минералогии ЮУ ФНЦ МиГ УрО РАН.

Холоднов В.В., доктор геолого-минералогических наук, главный научный сотрудник лаборатории петрологии магматических формаций Института геологии и геохимии им. А.Н. Заварицкого УрО РАН. 
UDC $553.08,552.514$

\title{
Co-Pd-Ag AND Th-REE MINERALIZATION OF HOST ROCKS FROM THE EXOCONTACT ZONE OF TASHLY-TAU MASSIF, KHUDOLAZ COMPLEX (SOUTH URALS): ORE SOURCES AND FLUID INCLUSIONS DATA
}

\author{
Ildar R. Rakhimov', \\ rigel92@mail.ru \\ Natalia N. Ankusheva², \\ ankusheva@mail.ru \\ Vladimir V. Kholodnov3, \\ holodnov@igg.uran.ru \\ 1 Institute of Geology UFSC RAS, \\ 16/2, K. Marks street, Ufa, 450077, Russia. \\ 2 Institute of Mineralogy SU FSC MG UB RAS, \\ 1, Ilmenskiy Reserve, Miass, 456317, Russia. \\ 3 Institute Geology and Geochemistry UB RAS, \\ 15, Acad. Vonsovsky street, Ekaterinburg, 620016, Russia.
}

The relevance of the study is caused by the absence of research of geochemical peculiarities and ore mineralization of exocontact rocks of ore-bearing massifs belonging to Khudolaz layered complex.

The aim of the research is mineralogical and geochemical characteristics of exocontact zone of Tashly-Tau massif and salt composition and PT-parameters of ore-forming fluid.

Analytical methods: geological field works, optical and electronic microscopy, EDS and WDS analyses of minerals compositions, XRF and ICP MS analyses of chemical compositions of rocks.

Results. Co-Pd-Ag and Th-REE mineralization consisted of Fe-Ni-cobaltite, Fe-Co-gersdorffite, michenerite, hessite, and Th-monazite was found in exocontact rocks of Khudolaz complex massifs. We subdivided the far and near exocontact zones of ore-bearing Tashly-Tau massif varying in the grade of sandstones metamorphism and metasomatism. In near exocontact zone, quartz-calcite veins with $\mathrm{Co}-\mathrm{Pd}-\mathrm{Ag}$ mineralization are identified. Sulfoarsenides contain Pd admixture up to 0,44 \% correlating with nickel content. Quartz and quartz-chloritefeldspar veins from near and far exocontacts zones contain disseminated Th-REE mineralization. Also, in late quartz veins, we detected goethite-hematite grains with impurity of $P d$ (up to $0,17-0,32 \%$ ) and $R h$ (up to $0,03 \%$ ). It is determined that the source of Co-Pd-Ag mineralization in host rocks is Tashly-Tau massif which rocks and ores were altered by hydrothermal fluid during the post-magmatic stage. We suppose that the source of Th-REE mineralization of exocontact zone are the rocks of Byagoda Suite (sandstones with clayey cement). According to fluid inclusion data, the earlier sulfide-quartz and late sulfide-quartz-carbonate veins are formed from the same hydrothermal $\mathrm{Na-K-Mg-chloride} \mathrm{fluid} \mathrm{at} \mathrm{temperatures} \mathrm{from} \mathrm{370-320} \mathrm{up} \mathrm{to} \mathrm{280-250}{ }^{\circ} \mathrm{C}$ diluted from 10,6 up to 6 wt \%, respectively.

Key words:

Exocontact zone, mineralogy, lithology, lithochemistry, cobaltite-gersdorffite solid solution, monazite, quartz, calcite, fluid inclusions.

The study is supported by the RFBR (no. 18-35-00391) and the State Contract of IG UFRC RAS (no. 0252-2017-0012) and State budget theme (no. 0393-2016-0020). The fluid inclusion study was supported by State Contract of the Institute of Mineralogy SU FRC MG UB RAS (project for 2019-2021).

\section{REFERENCES}

1. Salikhov D.N., Pshenichnyi G.N. Magmatizm i orudenenie zony ranney konsolidatsii Magnitogorskoy evgeosinklinali [Magmatism and ore mineralization of early consolidation of Magnitogorsk eugenosyncline]. Ufa, BFAS USSR Publ., 1984. $112 \mathrm{p}$.

2. Rakhimov I.R., Saveliev D.E., Puchkov V.N., Salikhov D.N Vishnevskiy A.V., Vladimirov A.G. First finds of platinum and palladium minerals in sulfide ores of the Khudolaz intrusive complex (Southern Urals). Doklady Earth Sciences, 2018, vol. 479 Iss. 2, pp. 439-442.

3. Rakhimov I.R., Vishnevskiy A.V., Zaylyamov Sh.R., Mikheeva A.V The mineralogy of rocks and ores from Tashly-Tau intrusion, Khudolazovsky complex. Geology. The bulletin of Department of Earth Science and Resources AS BR, 2018, no. 25, pp. 77-85. In Rus.

4. Rakhimov I.R., Saveliev D.E., Vishnevskiy A.V. Sulfide-platinum mineralization of altered gabbro from Malutka massif, Khudolazovsky complex: the influence of hydrothermal processes on mineral assemblage type. Bulletin of the Institute of Geology KSC UB RAS, 2019, no. 275, pp. 15-24. In Rus.
5. Borisenko A.S. Analiz solevogo sostava rastvorov gazovo-zhidkikh vklyucheniy $v$ mineralakh metodom kriometrii. Ispolzovanie metodov termobarogeokhimii pri poiskakh $i$ izuchenii rudnykh mestorozhdeniy [The analysis of fluid inclusion salt compositions in minerals by cryometry method. The application of thermobarogeochemistry methods for ore deposit prospecting and researchers]. Moscow Nedra Publ., 1982. pp. 37-46.

6. Bodnar R.J., Vityk M.O. Interpretation of microthermometric data for $\mathrm{H}_{2} \mathrm{O}-\mathrm{NaCl}$ fluid inclusions. Fluid inclusions in minerals: methods and applications. Pontignana-Siena, 1994, pp. 117-130.

7. Maslov V.A., Artyushkova O.V. Stratigrafiya $i$ korrelyatsiya devonskikh otlozheniy Magnitogorskoy megazony Yuzhnogo Urala [Stratigraphy and correlation of Devonian sediments of Magnitogorsk megazone, Southern Urals]. Ufa, DesignPolygraphService Publ., 2010. 88 p.

8. Melnichuk O.Yu., Fazliakhmetov A.M. K voprosu o sushchestvovanii mikrokontinenta $\mathrm{v}$ pozdnedevonskoe vremya na Srednem Urale. Problemy mineralogii, petrografii i metallogenii [About the existence of microcontinent in Late Devonian at the 
Middle Urals. The issues of mineralogy, petrography and metallogeny]. Nauchnye chteniya pamyati P.N. Chirvinskogo [Scientific Conference in memory of P.N. Chirvinsky]. Perm, Perm University Publ., 2017. pp. 148-155.

9. Yudovich Ya.E., Ketris M.P. Osnovy litokhimii [The Lithochemistry]. St-Petersburg, Nauka Publ., 2000. 479 p.

10. Kovalyov S.G., Timofeeva E.A., Pindyurina E.O. Monatsitovaya mineralizatsiya zapadnogo sklona Yuzhnogo Urala [Monazite mineralization from the Western slope of the Southern Urals] Geologicheskiy sbornik № 8. Informatsionnye materialy [Geological Bulletin № 8. Informational materials]. Ufa, IG USC RAS Publ., 2009. pp. 138-144.

11. Spiridonov E.M., Kulikova I.M., Sidorova N.V., Korotaeva N.N Troshkina A.N. Syngenetic zircon, monazite, xenotime, and Fapatite from apopicrite phlogopite-magnesite goumbeites of Beresovsky gold deposit, Urals. New data about minerals, 2013 , vol. 48, pp. 37-56. In Rus.

12. Mountain B.W., Wood S.A. Chemical controls on the solubility, transport, and deposition of platinum and palladium in hydrothermal solutions: a thermodynamic approach. Economic geology, 1988, vol. 83, pp. 492-510.

13. Kholodnov V.V., Bushlyakov I.N. Galogeny $v$ endogennom rudoobrazovanii [Halogens in endogenic ore formation]. Ekaterinburg, UB RAS Publ., 2002. 392 p.

14. Wood S.A., Mountain B.W. Thermodynamic constraints on the solubility of platinum and palladium in hydrothermal solutions: reassessment of hydroxide, bisulfide, and ammonia complexing. Economic geology, 1989, vol. 84, pp. 2020-2028.

15. Lanari P., Wagner T., Vidal O. A thermodynamic model for ditrioctahedral chlorite from experimental and natural data in the system $\mathrm{MgO}-\mathrm{FeO}-\mathrm{Al} 2 \mathrm{O} 3-\mathrm{SiO} 2-\mathrm{H} 2 \mathrm{O}$ : applications to P-T sections and geothermometry. Contributions to Mineralogy and Petrology, 2014, vol. 167, pp. 268-287.

16. Vishnevskiy A.V, Cherdantseva M.V. Raskristallizovannye kapli sulfidnogo rasplava iz massiva Rudnyi v S-Z Mongolii: modelnyi obekt dlya izucheniya raspredeleniya $\mathrm{i}$ form nakhozhdeniya elementov-primesey pri kristallizatsii prirodnykh sulfidnykh zhidkostey [Crystallized sulfide melt drops of Rudny massif, NW Mongolia: a model to study the distribution and forms of thace elements during the crystallization of natural sulfide liquids]. Materialy VII Sibirskoy nauchno-prakticheskoy konferentsii molodykh uchenykh po naukam o Zemle [Call for Papers of VII Youth Siberian Scientific-Practical Conference on Earth Sciences]. Novosibirsk, IGM SB RAS Publ., 2014. pp. 10-11.

17. Osbahr I., Klemd R., Oberthür T., Brätz H., Schouwstra R. Platinumgroup element distribution in base-metal sulfides of the Merensky Reef from the eastern and western Bushveld Complex, South Africa. Mineralium Deposita, 2013, vol. 48, Iss. 2, pp. 211-232.

18. Junge M., Wirth R., Oberthür T., Melcher F., Schreiber A. Mineralogical siting of platinum-group elements in pentlandite from the Bushveld Complex, South Africa. Mineralium Deposita, 2015. vol. 50, Iss. 1, pp. 41-54.

19. Holwell D.A., Zeinab A., Warda L. A., Smith D.J., Graham S.D., McDonald I., Smith J.W. Low temperature alteration of magmatic $\mathrm{Ni}-\mathrm{Cu}-\mathrm{PGE}$ sulfides as a source for hydrothermal $\mathrm{Ni}$ and PGE ores: a quantitative approach using automated mineralogy. Ore Geology Reviews, 2017, vol. 91, pp. 718-740.

20. Cullers R.L., Chaudhuri S., Arnold B., Lee M., Wolf C.Jr. Rare earth distributions in clay minerals and in the clay-sized fraction of the Lower Permian Havensville and Eskridge shales of Kansas and Oklahoma. Geochimica et Cosmochimica Acta, 1975, vol. 39, Iss. 12, pp. 1691-1703.

21. Caggianelli A., Fiore S., Mongelli G., Salvemini A. REE distribution in the clay fraction of pelites from the southern Apennines, Italy. Chemical Geology, 1992, vol. 99, Iss. 4, pp. 253-263.

22. Grigoriev N.A. Raspredelenie khimicheskikh elementov v verkhney chasti kontinentalnoy kory [Distribution of chemical elements in the upper part of the continental crust]. Ekaterinburg, UB RAS Publ., 2009. $382 \mathrm{p}$.

Received: 17 June 2020.

\section{Information about the authors}

Ildar R. Rakhimov, Cand. Sc., senior researcher, Institute of Geology UFRC RAS.

Natalia N. Ankusheva, Cand. Sc., researcher, Institute of Mineralogy SU FRC MG UB RAS.

Vladimir V. Kholodnov, Dr. Sc., main researcher, Institute of Geology and Geochemistry UB RAS. 